\title{
Modelling N2O dynamics of activated sludge biomass: Uncertainty analysis and pathway contributions
}

\author{
Domingo-Felez, Carlos; Smets, Barth F.
}

Published in:

Chemical Engineering Journal

Link to article, DOI:

10.1016/j.cej.2019.122311

Publication date:

2020

Document Version

Peer reviewed version

Link back to DTU Orbit

Citation (APA):

Domingo-Felez, C., \& Smets, B. F. (2020). Modelling $\mathrm{N}_{2} \mathrm{O}$ dynamics of activated sludge biomass: Uncertainty analysis and pathway contributions. Chemical Engineefing Journal, 379, [122311].

https://doi.org/10.1016/j.cej.2019.122311

\section{General rights}

Copyright and moral rights for the publications made accessible in the public portal are retained by the authors and/or other copyright owners and it is a condition of accessing publications that users recognise and abide by the legal requirements associated with these rights.

- Users may download and print one copy of any publication from the public portal for the purpose of private study or research.

- You may not further distribute the material or use it for any profit-making activity or commercial gain

- You may freely distribute the URL identifying the publication in the public portal

If you believe that this document breaches copyright please contact us providing details, and we will remove access to the work immediately and investigate your claim. 


\section{Accepted Manuscript}

Modelling $\mathrm{N}_{2} \mathrm{O}$ dynamics of activated sludge biomass: uncertainty analysis and pathway contributions

Carlos Domingo-Félez, Barth F. Smets

PII:

S1385-8947(19)31705-X

DOI: https://doi.org/10.1016/j.cej.2019.122311

Article Number: $\quad 122311$

Reference:

CEJ 122311

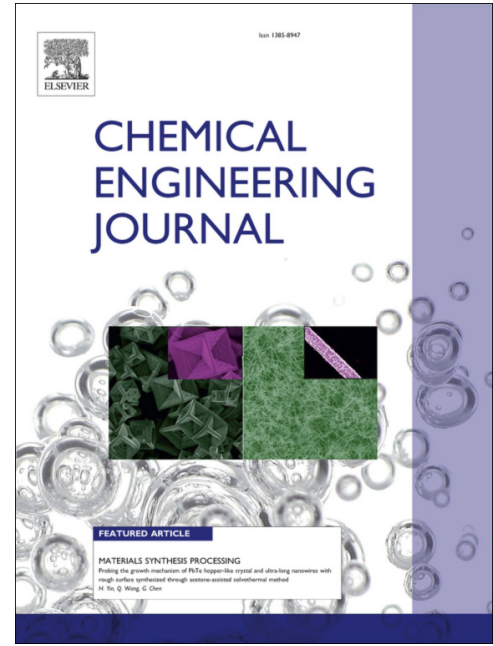

To appear in:

Chemical Engineering Journal

Received Date:

7 April 2019

Revised Date:

18 July 2019

Accepted Date:

20 July 2019

Please cite this article as: C. Domingo-Félez, B.F. Smets, Modelling $\mathrm{N}_{2} \mathrm{O}$ dynamics of activated sludge biomass: uncertainty analysis and pathway contributions, Chemical Engineering Journal (2019), doi: https://doi.org/10.1016/ j.cej.2019.122311

This is a PDF file of an unedited manuscript that has been accepted for publication. As a service to our customers we are providing this early version of the manuscript. The manuscript will undergo copyediting, typesetting, and review of the resulting proof before it is published in its final form. Please note that during the production process errors may be discovered which could affect the content, and all legal disclaimers that apply to the journal pertain. 


\section{Title}

Modelling $\mathrm{N}_{2} \mathrm{O}$ dynamics of activated sludge biomass: uncertainty analysis and pathway contributions

\section{Author list}

Carlos Domingo-Félez, Barth F. Smets*

Department of Environmental Engineering, Technical University of Denmark, Miljøvej 115, 2800 Kgs. Lyngby, Denmark

* Corresponding author:

Barth F. Smets, Phone: +45 4525 1600, Fax: +45 4593 2850, E-mail: bfsm@env.dtu.dk 


\section{Abstract}

Nitrous oxide $\left(\mathrm{N}_{2} \mathrm{O}\right)$ is a potent greenhouse gas emitted during biological wastewater treatment. A pseudomechanistic model describing three biological pathways for nitric oxide (NO) and $\mathrm{N}_{2} \mathrm{O}$ production was calibrated for mixed culture biomass from an activated sludge process using laboratory-scale experiments.

The model (NDHA) comprehensively describes $\mathrm{N}_{2} \mathrm{O}$ producing pathways by both autotrophic ammonium oxidizing bacteria and heterotrophic bacteria. Extant respirometric assays and anaerobic batch experiments were designed to calibrate endogenous and exogenous processes (heterotrophic denitrification and autotrophic ammonium/nitrite oxidation) together with the associated net $\mathrm{N}_{2} \mathrm{O}$ production. Ten parameters describing heterotrophic processes and seven for autotrophic processes were accurately estimated (variance/mean $<25 \%$ ). The model predicted accurately $\mathrm{NO}$ and $\mathrm{N}_{2} \mathrm{O}$ dynamics at varying dissolved oxygen, ammonium and nitrite levels, and was validated against an independent set of experiments with the same biomass.

In aerobic ammonium oxidation experiments the nitrifier denitrification and heterotrophic denitrification estimated pathway contributions increased at high nitrite and low oxygen concentrations; while the nitrifier nitrification pathway showed the largest contribution at high dissolved oxygen levels. The uncertainty of $\mathrm{N}_{2} \mathrm{O}$ emissions during model calibration is commonly overlooked, which limits the confidence of modelbased mitigation strategies. Here we show that the precision of the estimated parameters resulted in a low uncertainty of the $\mathrm{N}_{2} \mathrm{O}$ emission factors during aerobic ammonium oxidation at $\mathrm{DO} \approx 0.5 \mathrm{mg} / \mathrm{L}(1.2 \pm 0.1 \%)$ and $\mathrm{DO} \approx 2.0 \mathrm{mg} / \mathrm{L}(4.6 \pm 0.6 \%)$. 


\section{Highlights}

- Respirometric assays allow the calibration of a model describing $\mathrm{N}_{2} \mathrm{O}$ production.

- $\mathrm{NH}_{4}{ }^{+}$oxidation-driven $\mathrm{N}_{2} \mathrm{O}$ production increased at low $\mathrm{DO}$ and presence of $\mathrm{NO}_{2}{ }^{-}$.

- $\mathrm{N}_{2} \mathrm{O}$ emission factors of the calibrated model showed low uncertainty $(\leq 12 \%)$.

Keywords: Nitrous oxide, Activated Sludge, Modelling, Uncertainty, Respirometry 


\section{Introduction}

Nitrous oxide $\left(\mathrm{N}_{2} \mathrm{O}\right)$ is a greenhouse gas emitted at wastewater treatment plants. During biological nitrogen removal $\mathrm{N}_{2} \mathrm{O}$ is mainly emitted from aerated zones or during aerated periods due to physical stripping [1,2]. $\mathrm{N}_{2} \mathrm{O}$ is produced biologically by two microbial guilds: autotrophic ammonia oxidizing bacteria (AOB) and heterotrophic denitrifying bacteria (HB). AOB aerobically oxidize ammonium $\left(\mathrm{NH}_{4}^{+}\right)$into nitrite $\left(\mathrm{NO}_{2}{ }^{-}\right)$via hydroxylamine $\left(\mathrm{NH}_{2} \mathrm{OH}\right)$. Pure culture studies of model AOBs have shown that a side- reaction of hydroxylamine oxidation to nitrite (HAO-mediated) can produce nitric oxide (NO) and $\mathrm{N}_{2} \mathrm{O}$ regardless of dissolved oxygen (DO) levels [3,4]. Also, direct $\mathrm{N}_{2} \mathrm{O}$ production from hydroxylamine oxidation catalysed by the enzyme cytochrome (cyt) P460 was recently documented [5]. At low DO concentrations AOBs use nitrite as terminal electron acceptor producing $\mathrm{NO}$, further reduced to $\mathrm{N}_{2} \mathrm{O}$ [6-8]. Heterotrophic denitrification of nitrate $\left(\mathrm{NO}_{3}{ }^{-}\right)$to dinitrogen gas $\left(\mathrm{N}_{2}\right)$ is a 4-step process via $\mathrm{NO}_{2}{ }^{-}$, $\mathrm{NO}$ and $\mathrm{N}_{2} \mathrm{O}$ [9].

$\mathrm{AOB}$ and $\mathrm{HB}$ have been suggested as equal contributors to $\mathrm{N}_{2} \mathrm{O}$ production during traditional nitrification and denitrification processes [10-13]. However, in-situ quantification of AOB and HB contributions via nitrogen and oxygen isotopic signatures is rare in full-scale systems compared to lab-scale $[14,15]$. To gain insights on the process contributions bulk $\mathrm{N}_{2} \mathrm{O}$ emissions are correlated to operational parameters, or by multiple linear regression to operational factors [16]. In nitrogen removing systems $\mathrm{N}_{2} \mathrm{O}$ production is associated to high $\mathrm{NH}_{4}{ }^{+}$and $\mathrm{NO}_{2}{ }^{-}$, and low DO concentrations [17-19]. The $\mathrm{NH}_{4}{ }^{+}$load and influent $\mathrm{NH}_{4}{ }^{+}$ concentration have been correlated to $\mathrm{N}_{2} \mathrm{O}$ emissions from aerobic zones operating at high DO concentrations $[10,20]$. As the direct precursor of $\mathrm{N}_{2} \mathrm{O}$ in most of the biological pathways, NO has shown the highest correlations with $\mathrm{N}_{2} \mathrm{O}$ but $\mathrm{NO}$ is often not measured $[18,19,21]$.

Mechanistic models for $\mathrm{N}$-removal have been extended to include $\mathrm{N}_{2} \mathrm{O}$ and $\mathrm{NO}$ production processes, which allow the prediction of individual pathway contributions. Three biological $\mathrm{N}_{2} \mathrm{O}$ production pathways are considered to co-occur: the nitrifier nitrification (NN), the nitrifier denitrification (ND) and the heterotrophic denitrification (HD) pathway. Models considering the three pathways have better predictive capabilities than two pathway models [22], but the mathematical description of $\mathrm{N}_{2} \mathrm{O}$ production (i.e. number of processes and variables) varies between model structures. For example, several models describe the ND pathway as direct $\mathrm{NO}_{2}^{-}$reduction to $\mathrm{N}_{2} \mathrm{O}[23,24]$, not considering $\mathrm{NO}$ an intermediate of autotrophic denitrification $[3,8]$. Hence, NO model predictions would overestimate other NO-producing pathways to fit NO measurements (e.g. NN, HD). Most $\mathrm{N}_{2} \mathrm{O}$ models associate the AOB-driven $\mathrm{NH}_{2} \mathrm{OH}$ oxidation reaction to obligate DO reduction $[23,24]$ even though $\mathrm{O}_{2}$ is not required as electron acceptor, and anoxic $\mathrm{NH}_{2} \mathrm{OH}$ oxidation yields $\mathrm{N}_{2} \mathrm{O}[4,25]$. The NDHA model considers the three biological pathways for $\mathrm{NO}$ and $\mathrm{N}_{2} \mathrm{O}$ production and abiotic contribution, DO-independent $\mathrm{NH}_{2} \mathrm{OH}$ oxidation, and was previously calibrated for an AOB-enriched biomass [25]. 
Validation of $\mathrm{N}_{2} \mathrm{O}$ model response typically relies on regression coefficients between data and simulation (e.g. $\mathrm{R}^{2}$ ). However, more rigorous analysis of residuals is required to validate the model response [26]: the performance of two models cannot be compared via visual inspection [24] or regression coefficients, which do not identify structural deficiencies [27]. The frequency of data acquisition from online sensors (e.g. DO, $\mathrm{N}_{2} \mathrm{O}$ ) impacts the calibration results of $\mathrm{N}_{2} \mathrm{O}$ models. Methods used to calculate confidence regions estimated biokinetic parameters often rely on structural assumptions of the residuals, but are often overlooked: gaussian distribution and interdependency at different lag times [28]. Testing the model response can avoid over interpretation of the calibration datasets and parameter uncertainty underestimation (e.g. variance/mean $\ll 0.001 \%$ [29]). The carbon footprint of wastewater systems is very sensitive to $\mathrm{N}_{2} \mathrm{O}$ emissions [30] and precise predictions are desired. Yet, the uncertainty of $\mathrm{N}_{2} \mathrm{O}$ emissions associated to parameter estimation is barely studied $[25,31]$. Here, we aim at calibrating the NDHA model for a mixed culture biomass from a fullscale wastewater treatment plant via respirometric assays to assess the uncertainty of $\mathrm{N}_{2} \mathrm{O}$ emissions.

\section{Objectives}

- Quantify $\mathrm{N}_{2} \mathrm{O}$ dynamics from AS biomass via extant respirometric assays.

- Calibrate the NDHA model to describe $\mathrm{N}$-removing processes and $\mathrm{N}_{2} \mathrm{O}$ production of the AS biomass and assess the accuracy of estimated parameters.

- Evaluate the predictive ability of the calibrated model against a different AS biomass dataset.

- Quantify the uncertainty of $\mathrm{N}_{2} \mathrm{O}$ emissions during aerobic $\mathrm{NH}_{4}{ }^{+}$removal.

\section{Materials and Methods}

\subsection{Extant respirometric assays}

Mixed liquor from a full-scale phase-isolated activated sludge (AS) wastewater treatment plant (700,000 PE Lynetten, Copenhagen, Denmark) was sampled and aerated overnight; it is here referred to as the AS biomass. To prevent significant changes in biomass composition biomass was discarded, and new samples taken, after two days of experimentation [32]. Biomass samples were harvested by centrifugation at 4700 rpm for 3 min, washed and resuspended in nitrogen-free mineral medium (modified after Graaf et al., 1996) three times to eliminate any soluble substrates. Assays were performed in parallel at $25^{\circ} \mathrm{C}$ in two $400-\mathrm{mL}$ jacketed glass vessels completely filled with biomass and sealed with the insertion of a Clark-type polarographic DO electrode (YSI Model 5331, Yellow Springs, OH). Biomass samples were saturated with air, pure oxygen or dinitrogen gas prior to the initiation of the assays. A decrease in the DO level in the vessel due to substrate oxidation was measured by the DO probe and continuously acquired $(0.2 \mathrm{~Hz})$ by a personal computer interfaced to a DO monitor (YSI Model 5300, Yellow Springs, OH) by a multi-channel data acquisition device (LabPC+, National Instruments, Austin, TX). pH was also monitored (WTW GmbH, 
Weilheim, Germany) and liquid $\mathrm{NO}$ and $\mathrm{N}_{2} \mathrm{O}$ concentrations were measured with Clark-type microsensors (NO-500, N2O-R, Unisense A/S, Aarhus, Denmark). Stock solutions for all the reagents were prepared from high-purity chemicals for $\mathrm{NH}_{4} \mathrm{HCO}_{3}, \mathrm{NH}_{2} \mathrm{OH} \cdot \mathrm{HCl}, \mathrm{NaNO}_{2}, \mathrm{HCOONa}, \mathrm{C}_{2} \mathrm{H}_{3} \mathrm{NaO}_{2}, \mathrm{C}_{3} \mathrm{H}_{5} \mathrm{NaO}_{2}(\operatorname{Sigma}$ Aldrich) and by initially sparging $\geq 99.998 \%, 99.5 \%$ gas $\mathrm{N}_{2} \mathrm{O}$ and $\mathrm{O}_{2}$ (Sigma-Aldrich, AGA). Photometric test kits were used to analyse N species (1.14752, 1.09713, 1.14776, Merck KGaA, Darmstadt, Germany). Biomass content (MLSS, MLVSS) was measured in duplicates according to APHA [34] and estimates of nitrifying fraction were made from stoichiometric principles [35].

\subsection{Experimental Design}

The experiments were designed to obtain informative data on $\mathrm{N}_{2} \mathrm{O}$ dynamics from mixed liquor biomass. Respirometric approaches were taken (on-line, high-rate $\mathrm{O}_{2}$ and $\mathrm{N}_{2} \mathrm{O}$ measurements) as they are more suited for accurate parameter estimation in comparison to substrate depletion experiments [36]. The kinetics of the oxidation of the primary $\mathrm{N}$-species $\left(\mathrm{NH}_{4}{ }^{+}\right.$and $\left.\mathrm{NO}_{2}{ }^{-}\right)$were individually and step-wise measured via extant respirometry at varying DO concentrations, while simultaneously measuring $\mathrm{N}_{2} \mathrm{O}$. Batch experiments were conducted to measure the heterotrophic and abiotic contributions to total $\mathrm{N}_{2} \mathrm{O}$ production (Table 1). During anoxic experiments processes were measured both in absence and presence of supplied organic carbon (mixture of formate + acetate + propionate) under $\mathrm{NO}_{\mathrm{x}}^{-}$excess. With no organic carbon supply $\mathrm{NO}_{\mathrm{x}}^{-}$ reduction was assumed supported by hydrolysis products originated from biomass decay (S-0).

A scenario (e.g. (Scenario C)) was defined as a group of experiments with the same primary N-species added by pulses (Table 1). At least duplicate experiments were performed for each N-species. The oxygen consumption rate was the additive effect of several independent oxygen consumption processes, potentially including endogenous respiration, $\mathrm{NO}_{2}{ }^{-}$respiration, and $\mathrm{NH}_{4}{ }^{+}$-respiration (S-I). By sequentially following the respirometric response from more to less oxidized $\mathrm{N}$-species (i.e., first $\mathrm{NO}_{2}^{-}$, then $\mathrm{NH}_{4}^{+}$) the identifiability of nitrification kinetic parameters increases [37].

Table 1 - Experimental design for respirometric assays (Scenarios A-C) and for model validation (Scenarios D-E).

Scenario Oxygen level

Anoxic

(A)

Non-aerated: from excess DO (air-sat) into anoxia dynamically

(B) Anoxic

Non-aerated: from

(C) excess DO $\left(\mathrm{O}_{2}\right.$-sat $)$ into anoxia dynamically

(D) Constant aeration (high and low DO)

\section{Species added} $\mathrm{COD}+\mathrm{NO}_{3}{ }^{-1}$

$\mathrm{COD}+\mathrm{NO}_{2}^{-} /$

$\mathrm{COD}+\mathrm{N}_{2} \mathrm{O}$

COD

$\mathrm{NO}_{3}^{-} / \mathrm{NO}_{2}^{-}$

$\mathrm{NH}_{4}^{+} / \mathrm{NH}_{2} \mathrm{OH} /$

$\mathrm{NO}_{2}^{-}$

$\mathrm{NH}_{4}{ }^{+}$
Species monitored $\mathrm{NO}_{3}^{-}, \mathrm{NO}_{2}^{-}, \mathrm{N}_{2} \mathrm{O}$, $\mathrm{NH}_{4}^{+}$

DO

$\mathrm{N}_{2} \mathrm{O}, \mathrm{NO}$

$\mathrm{DO}, \mathrm{N}_{2} \mathrm{O}, \mathrm{NO}$

DO, $\mathrm{N}_{2} \mathrm{O}, \mathrm{NH}_{4}{ }^{+}, \mathrm{NO}_{2}{ }^{-}$

\section{Targeted Processes}

Heterotrophic denitrification, hydrolysis

Biomass decay, hydrolysis

HB-driven $\mathrm{NO} / \mathrm{N}_{2} \mathrm{O}$

dynamics

$\mathrm{NH}_{4}{ }^{+}, \mathrm{NO}_{2}{ }^{-}$removal

$\mathrm{AOB} / \mathrm{HB}$-driven $\mathrm{NO} / \mathrm{N}_{2} \mathrm{O}$

dynamics

$\mathrm{NH}_{4}{ }^{+}, \mathrm{NO}_{2}{ }^{-}$removal, $\mathrm{N}_{2} \mathrm{O}$

dynamics 


\subsection{Dataset for model evaluation}

Separate batch experiments were executed in a 3-L lab-scale reactor with mixed liquor biomass from the same WWTP (Lynetten, Copenhagen, Denmark): (D) Four batch tests received sequential increasing $\mathrm{NH}_{4}{ }^{+}$ pulses while subject to constant aeration $(2.3,3.6,4.7,5.5 \mathrm{mgN} / \mathrm{L})$; (E) three batch tests received a singular $\mathrm{NH}_{4}{ }^{+}$pulse $\left(4 \mathrm{mgNH}_{4}^{+}-\mathrm{N} / \mathrm{L}\right)$ followed by addition of either $\mathrm{NO}_{2}^{-}$or $\mathrm{NO}_{3}^{-}$when reaching low DO concentrations. The dataset comprises online $\mathrm{DO}, \mathrm{pH}$ and $\mathrm{N}_{2} \mathrm{O}$ liquid measurements together with grab samples for $\mathrm{NH}_{4}^{+}$and $\mathrm{NO}_{2}{ }^{-}$. Details of these experiments have been reported before [35].

\subsection{Model description}

The NDHA model was proposed to describe $\mathrm{NO} / \mathrm{N}_{2} \mathrm{O}$ dynamics under a variety of conditions for biomass containing both autotrophic (ammonium and nitrite oxidizing bacteria) and heterotrophic fractions [38]. Shortly, it considers $\mathrm{N}_{2} \mathrm{O}$ formation from two autotrophic and one heterotrophic biological pathway, plus abiotic $\mathrm{N}_{2} \mathrm{O}$ formation based on recent findings [39]. Unlike any other model, NDHA qualitatively captures $\mathrm{NO}$ and $\mathrm{N}_{2} \mathrm{O}$ profiles observed at both high and low DO. The observed $\mathrm{N}_{2} \mathrm{O}$ production during $\mathrm{NH}_{4}{ }^{+}$ oxidation at high DO is described by the Nitrifier Nitrification pathway (NN) [20], where $\varepsilon_{A O B}$ describes the fraction of $\mathrm{NH}_{2} \mathrm{OH}$ converted to $\mathrm{NO}$ instead of $\mathrm{NO}_{2}^{-}$. The Autotrophic Denitrification pathway (ND) captures the increasing $\mathrm{NO}$ production at low $\mathrm{DO}$ and in the presence of $\mathrm{NO}_{2}^{-}$, where $\eta_{N I R}$ describes the $\mathrm{NO}_{2}{ }^{-}$ reduction to $\mathrm{NO}$ inhibited by DO. The higher $\mathrm{N}_{2} \mathrm{O}$ yield $\left(\mathrm{N}_{2} \mathrm{O}\right.$ produced / $\mathrm{N}$-species consumed from $\mathrm{NH}_{2} \mathrm{OH}$ oxidation, as observed for pure AOB cultures and mixed communities, is also captured by the model as $\mathrm{NH}_{2} \mathrm{OH}$ is the electron donor in both $\mathrm{NN}$ and $\mathrm{ND}$ pathways, following the oxygen-independent $\mathrm{NH}_{2} \mathrm{OH}$ oxidation driven by $\mathrm{HAO}[3,5,25,40]$. The two autotrophic pathways produce $\mathrm{NO}$, which is reduced to $\mathrm{N}_{2} \mathrm{O}$ in a last combined step, where $\eta_{N O R}$ describes the autotrophic $\mathrm{NO}$ reduction to $\mathrm{N}_{2} \mathrm{O}$. A 4-step heterotrophic denitrification model was considered based on earlier reports [41]. Individual process rates and inhibition/substrate coefficients were used as suggested for systems with low substrate accumulation. Here we aim to calibrate the NDHA model for AS biomass (S-I).

\subsection{Sensitivity analysis and uncertainty evaluation}

A global sensitivity analysis (GSA) was performed to identify the most determinant parameters for model outputs via Monte Carlo simulations. Uncertainty from model parameters is propagated as $10-25-50 \%$ uniform variations from their default value to model outputs [42] (S-II). Latin hypercube sampling (LHS) was used to cover the parameter space and the Standardized Regression Coefficient method was used to calculate the sensitivity measure $\beta_{\mathrm{i}}$, which indicates the effect of the parameter on the corresponding model 
output (convergence found for 1200 samples, $\beta_{2}$ threshold $>0.7$ ) [43]. The duration of every experiment was discretized in 400 time steps, and the GSA run at each point, obtaining a dynamic profile of global sensitivity metrics.

The effect of the estimated uncertainty in kinetic parameters on the model output was evaluated by Monte Carlo simulations. Parameter values were sampled via LHS $(n=500)$ for two cases: $(1)$ from literature as in the GSA, and (2), from the distributions obtained after parameter estimation. Model simulations were performed in the Matlab environment (The Mathworks Inc., Natick, USA).

\subsection{Parameter estimation procedure}

The objective of the parameter estimation procedure was to sequentially estimate kinetic parameters that describe: (1) rates of hydrolysis, heterotrophic denitrification and heterotrophic oxygen consumption; (2) dynamics of nitrogen oxides (including $\mathrm{NO}$ and $\mathrm{N}_{2} \mathrm{O}$ ) under anoxia and endogenous conditions; (3) $\mathrm{NO}_{2}^{-}$ oxidation; (4) $\mathrm{NH}_{4}{ }^{+}$oxidation; (5) $\mathrm{N}_{2} \mathrm{O}$ production associated with $\mathrm{NH}_{4}{ }^{+}$oxidation (S-0). The error function for problem minimization was defined as:

$\operatorname{RMNSE}=\sum_{\mathrm{k}}^{\mathrm{m}} \sum_{\mathrm{j}}^{\mathrm{n}} \frac{\mathrm{RMSE}_{\mathrm{j}}}{\overline{\mathrm{y}}_{\mathrm{obs}, \mathrm{j}}} ;$ $\operatorname{RMSE}_{j}=\sqrt{\frac{\sum_{i}^{p}\left(y_{\text {sim }, i}-y_{o b s, i}\right)^{2}}{p}}$

Where $m$ is the number of experiments in one scenario (e.g. 2 experiments where $\mathrm{NH}_{4}{ }^{+}$is added: Scenario C), $n$ the number of data series in one experiment (e.g. $\mathrm{NO}, \mathrm{N}_{2} \mathrm{O}$ ), $p$ the number of experimental points in each data series, $y_{\text {sim }, i}$ the model prediction and $y_{o b s, i}$ the experimental data at time $i$. A global search algorithm (Global Search) was used over a wide parameter space, followed by a local minimization algorithm (Pattern Search). Parameters describing the elemental biomass composition (e.g. $\left.\mathrm{i}_{\mathrm{NXB}}\right)$, yield and temperature coefficients were fixed at default values and not subject to estimation. Newly estimated parameters were fixed at their best-fit estimate for the following parameter estimation step.

\subsection{Validation of model response and parameter estimates}

To test the validity of the model response (i.e., the adequacy of model to predict the observed data points) the interdependency of residuals $\left(y_{s i m, i}-y_{\text {obs }, i}\right)$ was analysed by autocorrelation for different lag times [28]. The quality of the model fit was evaluated via correlation coefficients $\left(\mathrm{R}^{2}\right)$ and more rigorously by an Fdistribution test, with the hypothesis of a linear regression with simultaneous unit slope and zero intercept [27]. The identifiability of a parameter subset $K$ was evaluated by a collinearity index $\left(\gamma_{K}\right)$, which quantifies the near-linear dependence of local sensitivity functions. A collinearity index higher than 15 indicates a 
poorly identifiable parameter subset $K$ [44]. Approximate confidence regions were calculated following J $\mathrm{J}_{\text {crit }}$ $=\mathrm{J}_{\text {opt }}\left(1+\frac{\mathrm{p}}{\mathrm{N}_{\mathrm{data}}-\mathrm{p}} \mathrm{F}_{\alpha, \mathrm{p}, \mathrm{N}_{\mathrm{data}}-\mathrm{p}}\right)[45]$.

\subsection{Case study: nitrification/denitrification cycle}

To study the sensitivity of $\mathrm{N}_{2} \mathrm{O}$ and $\mathrm{NO}$ emissions during $\mathrm{NH}_{4}^{+}$removal with AS biomass a nitrification/denitrification cycle in a sequencing-batch reactor was simulated (S-II). Initially, $\mathrm{NH}_{3}$ was added as a pulse (30 $\mathrm{mgN}_{\text {tot }} / \mathrm{L}$ ), consumed during $2 \mathrm{~h}$ of constant aeration, followed by $0.5 \mathrm{~h}$ anoxic period with excess carbon dosage (200 mgCOD/L). To investigate the effect of DO concentration on $\mathrm{N}_{2} \mathrm{O}$ emissions the aeration rates $\left(k_{L} a_{O 2}\right)$ were adjusted to attain DO levels of approximately 0.5 and $2 \mathrm{mg} / \mathrm{L}$ respectively. The biomass content was set to 4 gTSS/L and stripping for $\mathrm{N}_{2} \mathrm{O}$ and $\mathrm{NO}$ was calculated from diffusivity corrections [46]. A global sensitivity analysis was performed when removal rates were stable within one cycle (SRC method). After validating the model, the same nitrification/denitrification cycle was re-evaluated to study the pathway contributions and the uncertainty of $\mathrm{N}_{2} \mathrm{O}$ emissions associated to kinetic parameters.

\section{Results}

\subsection{Sensitivity analysis on the nitrification/denitrification case study}

Simulation results for the nitrification/denitrification case study were used to investigate the main processes driving $\mathrm{N}_{2} \mathrm{O}$ production. The majority of $\mathrm{N}_{2} \mathrm{O}$ was produced and emitted during the aerobic part of the cycle at both low and high aeration rates, when $\mathrm{NH}_{4}{ }^{+}$oxidation occurs. The highest ranked parameters were associated to DO and $\mathrm{NO}_{2}$ sensitivity. The GSA ranking showed that at high DO the two most sensitive parameters correspond to $\mathrm{AOB}$, followed by $\mathrm{NOB}$ and heterotrophic $\mathrm{NO}_{2}{ }^{-}$reduction. At low $\mathrm{DO}$ all three microbial groups share high sensitivity (S-II). Overall, the results highlight the importance of interactions between $\mathrm{AOB}$, NOB, and $\mathrm{HB}$, on the $\mathrm{N}_{2} \mathrm{O}$ production from AS biomass during aerobic $\mathrm{NH}_{4}{ }^{+}$oxidation. After identifying the key parameters activity tests can be designed accordingly.

\subsection{Experimental results}

\section{Biomass activity tests}

During Scenario A experiments heterotrophic denitrification and hydrolysis of biomass decay products were monitored. Under anoxic conditions the hydrolytic processes released $\mathrm{NH}_{4}{ }^{+}$into the bulk $\left(0.16 \mathrm{mgNH}_{4}{ }^{+}-\right.$ $\mathrm{N} / \mathrm{gVSS} / \mathrm{h}$ ). Simultaneously, biodegradable carbon was released and heterotrophic denitrification of $\mathrm{NO}_{3}^{-}$, $\mathrm{NO}_{2}{ }^{-}$and $\mathrm{N}_{2} \mathrm{O}$ was measured individually at excess electron acceptor concentrations $(1.5,2.5$ and 4.7 $\mathrm{mgN} / \mathrm{gVSS} / \mathrm{h}$ respectively) (Figure 1A). The specific denitrification rates were significantly higher in the 
presence of excess electron donor (mix of C-sources) compared to endogenous conditions (7, 6.2 and 12 $\mathrm{mgN} / \mathrm{gVSS} / \mathrm{h}$ ). The maximum $\mathrm{N}_{2} \mathrm{O}$ reduction rate varied 3-fold in the $\mathrm{pH}$ range $6.5-9$, with a maximum at around $\mathrm{pH}=8$ (Figure 1B). Under endogenous aerobic conditions, a positive oxygen uptake rate was constantly measured, reflecting respiration of the biodegradable carbon and $\mathrm{NH}_{4}{ }^{+}$released during hydrolysis (S-V). Addition of external biodegradable C-source increased the oxygen consumption rate compared to endogenous conditions ( $35 \mathrm{vs} 4.5-7 \mathrm{mgCOD} / \mathrm{gVSS} / \mathrm{h}$ ).

Scenario $\mathrm{C}$ experiments were designed to study oxygen uptake associated with nitrification and started at excess DO $(>30 \mathrm{mg} / \mathrm{L})$. The oxygen uptake showed a dynamic response, increasing from a positive baseline up to a maximum rate after the $\mathrm{N}$ pulse, and decreasing until either the $\mathrm{N}$-species $\left(\mathrm{NH}_{4}{ }^{+}, \mathrm{NO}_{2}{ }^{-}\right)$or $\mathrm{DO}$ reached limiting conditions $\left(\mathrm{OUR}_{\mathrm{max}, \mathrm{NH} 4}=31 \mathrm{mgO}_{2} / \mathrm{gVSS} \mathrm{h}, \mathrm{OUR}_{\max , \mathrm{NO} 2}=18 \mathrm{mgO}_{2} / \mathrm{gVSS} / \mathrm{h}\right)($ Figure 1C,D).
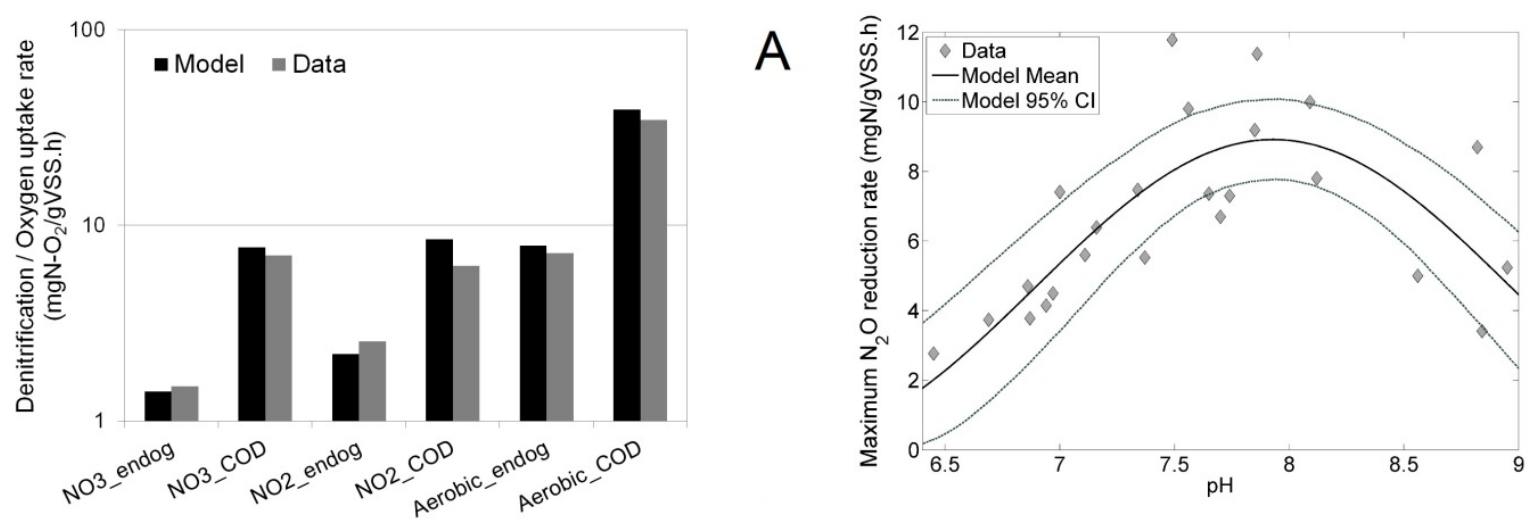

B
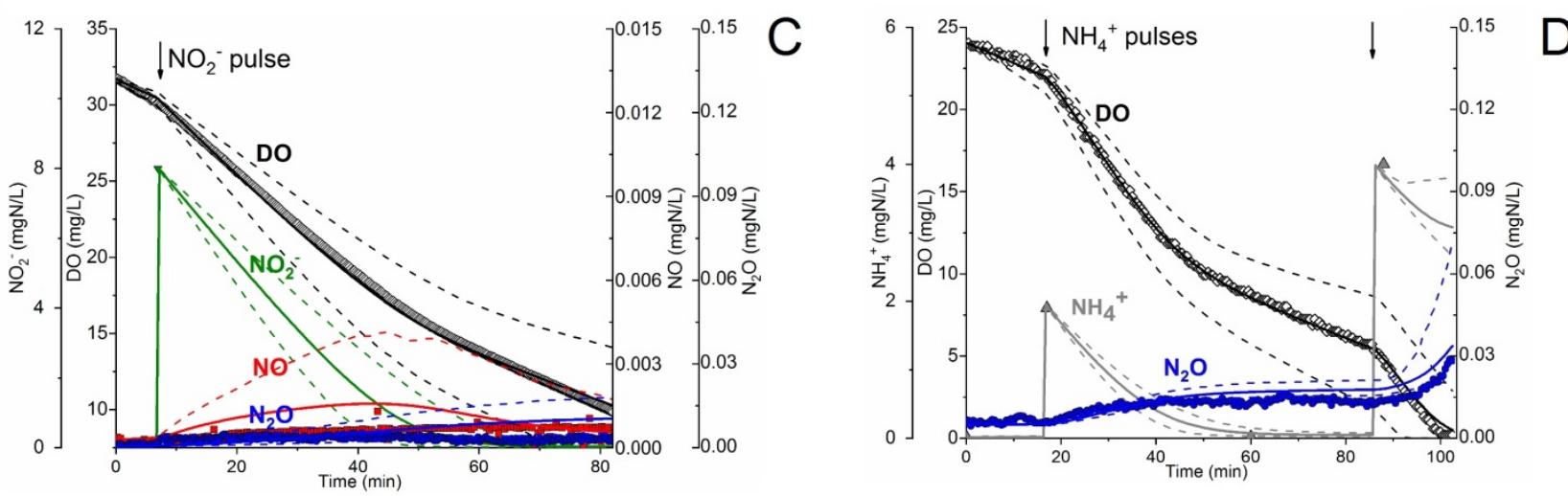

Figure 1 - Experimental and modelling results for heterotrophic processes (A, Scenario A), Anoxic $\mathrm{N}_{2} \mathrm{O}$ reduction dependency on $\mathrm{pH}\left(\mathrm{B}\right.$, Scenario A), Aerobic $\mathrm{NO}_{2}{ }^{-}$oxidation (C, Scenario C), Aerobic $\mathrm{NH}_{4}{ }^{+}$oxidation (D, Scenario C). Experimental data (markers), best-fit model simulations (solid lines), 95\% confidence intervals (dashed lines).

\section{$\mathrm{N}_{2} \mathrm{O}$ dynamics during respirometric assays}


During Scenario B experiments under anoxic conditions, $\mathrm{NO}$ and $\mathrm{N}_{2} \mathrm{O}$ transiently accumulated after $\mathrm{NO}_{2}{ }^{-}$ and $\mathrm{NO}_{3}{ }^{-}$pulses $(\mathbf{S}-\mathbf{V})$, but did not accumulate after sole $\mathrm{NH}_{4}{ }^{+}$addition. After a $\mathrm{NO}_{3}{ }^{-}$pulse $\mathrm{NO}$ concentration increased until reaching a maximum, followed by a steady decrease. The same trend was observed for $\mathrm{N}_{2} \mathrm{O}$ but delayed with respect to $\mathrm{NO} ; \mathrm{N}_{2} \mathrm{O}$ accumulation stopped after $\mathrm{NO}$ disappeared, followed by a continuous decrease. Similar $\mathrm{NO}$ and $\mathrm{N}_{2} \mathrm{O}$ dynamics was observed after $\mathrm{NO}_{2}{ }^{-}$addition (Figure $\mathbf{2 A , B}$ ), indicating $\mathrm{NO}$ as $\mathrm{N}_{2} \mathrm{O}$ precursor during heterotrophic denitrification.

In Scenario $\mathrm{C}$ experiments neither $\mathrm{NO}$ nor $\mathrm{N}_{2} \mathrm{O}$ accumulated in the bulk during $\mathrm{NO}_{2}^{-}$oxidation (Figure 1C). $\mathrm{NH}_{4}{ }^{+}$oxidation lead to a low NO accumulation compared to the simultaneous and higher $\mathrm{N}_{2} \mathrm{O}$ increase (Figure 1D, 2C). The sole addition of $\mathrm{NH}_{2} \mathrm{OH}$, an intermediate of $\mathrm{NH}_{4}^{+}$oxidation to $\mathrm{NO}_{2}^{-}$, yielded the highest $\mathrm{NO}$ and $\mathrm{N}_{2} \mathrm{O}$ accumulation rates $\left(\mathrm{N}_{2} \mathrm{O}\right.$ accumulation rates $\approx 0-0.05-0.2 \mathrm{mgN} / \mathrm{gVSS} / \mathrm{h}$ for $\mathrm{NO}_{2}^{-}$, $\mathrm{NH}_{4}{ }^{+}$and $\mathrm{NH}_{2} \mathrm{OH}$ ) (Figure 2C). Irrespective of the $\mathrm{N}$-species being oxidized, at the onset of anoxia NO and $\mathrm{N}_{2} \mathrm{O}$ concentrations increased. First NO, and then $\mathrm{N}_{2} \mathrm{O}$, reached a maximum followed by a steady decrease, in a similar pattern to that observed after $\mathrm{NO}_{2}{ }^{-}$or $\mathrm{NO}_{3}{ }^{-}$pulses in anoxic experiments (Scenario B). The NO and $\mathrm{N}_{2} \mathrm{O}$ decrease indicate net consumption rates, but simultaneous production/consumption could still occur.
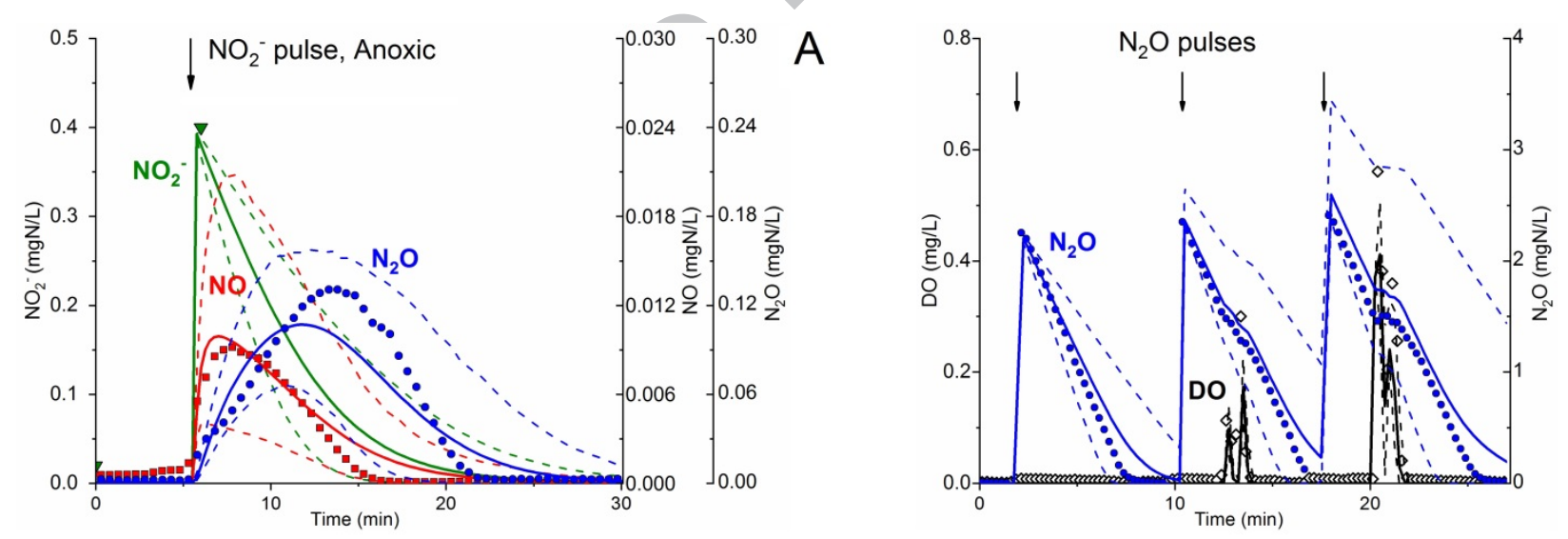

B

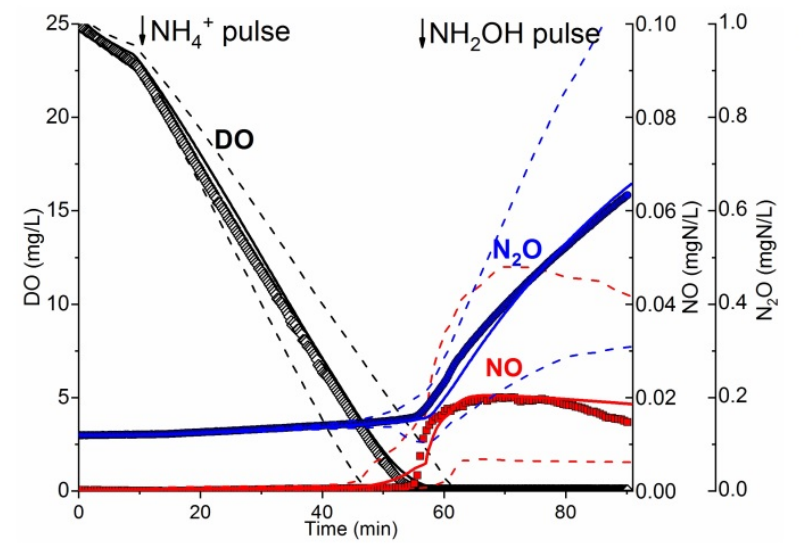

C

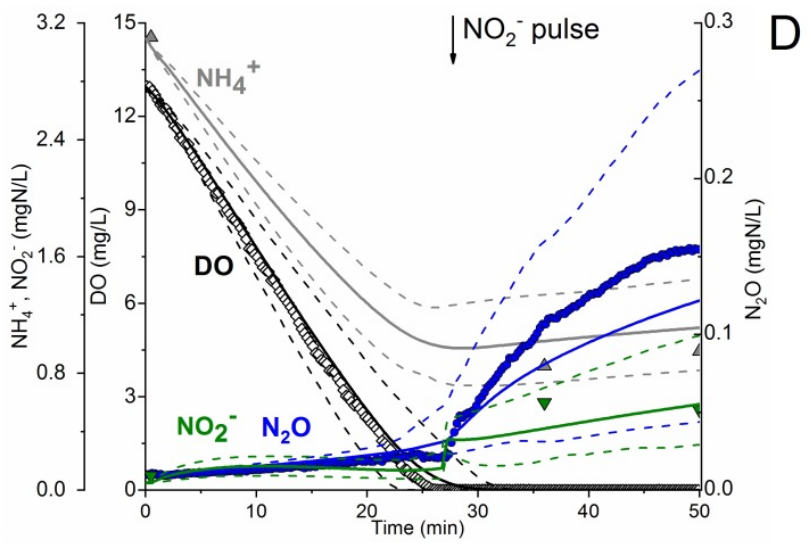


Figure 2 - Experimental and modelling results obtained during parameter estimation (A, Scenario A; B, Scenario B; C, Scenario C) and after parameter estimation (D, Scenario C). $\mathrm{NO}$ and $\mathrm{N}_{2} \mathrm{O}$ dynamics after anoxic $\mathrm{NO}_{2}{ }^{-}$pulse under endogenous conditions (A). $\mathrm{N}_{2} \mathrm{O}$ consumption in the absence and presence of DO (DO pulses at $\mathrm{t}=13,21$ $\min$ ) (B). Oxygen consumption, $\mathrm{NO}$ and $\mathrm{N}_{2} \mathrm{O}$ dynamics after $\mathrm{NH}_{4}{ }^{+}$pulse addition $(\mathrm{t}=10 \mathrm{~min})(\mathrm{C})$. Oxygen consumption and $\mathrm{N}_{2} \mathrm{O}$ dynamics after $\mathrm{NH}_{4}{ }^{+}$pulse addition (D). Experimental data (markers), best-fit simulations (solid lines), 95\% confidence intervals for the uncertainty of all model parameters (dashed lines).

\subsection{Modelling results}

The applicability of the NDHA model to describe the observed data was examined. Because GSA results highlighted the interactions between $\mathrm{HB}$, NOB and $\mathrm{AOB}$ during $\mathrm{N}_{2} \mathrm{O}$ production a step-by-step calibration procedure was followed that included all sensitive processes. First, the release of $\mathrm{NH}_{4}{ }^{+}$and biodegradable organic carbon was studied under aerobic and anoxic conditions. The model simulated the anoxic $\mathrm{NH}_{4}{ }^{+}$ release from hydrolysis $\left(\mathrm{R}^{2}=0.97\right)$, and $\mu_{H B}$ was estimated to fit the oxygen uptake measured during Scenario A experiments (Table 2). Then, the maximum denitrification rates on $\mathrm{NO}_{3}{ }^{-}$and $\mathrm{NO}_{2}{ }^{-}\left(\mu_{N A R}, \mu_{N I R}\right)$ were estimated from experiments in Scenario $A\left(\mathrm{R}^{2}>0.96\right)$. With the $\mathrm{N}_{2} \mathrm{O}$ dataset the pH-dependency of the $\mathrm{N}_{2} \mathrm{O}$ reduction was fitted using a sinusoidal model [47] ( $w_{N O S}, p H_{\text {opt.NOS }}$ ) while the substrate affinity for $\mathrm{N}_{2} \mathrm{O}$ reduction $\left(K_{H B . N 2 O}\right)$ could be estimated from the $\mathrm{N}_{2} \mathrm{O}$-limited part of individual experiments from Scenario A $\left(\mathrm{R}^{2}>0.98\right)$. The $\mathrm{NO}$ and $\mathrm{N}_{2} \mathrm{O}$ concentrations from experiments in Scenario $\mathrm{B}$, under endogenous respiration, were sensitive to changes in the affinity to biodegradable carbon for $\mathrm{NO}_{2}^{-}, \mathrm{NO}$ and $\mathrm{N}_{2} \mathrm{O}$ reduction (S-III). Hence, the $\mathrm{NO}$ and $\mathrm{N}_{2} \mathrm{O}$ datasets were used to identify three of the affinities that were within the top sensitive parameters $\left(K_{\text {HB.S.NIR }}, K_{\text {HB.S.NOR }}, K_{\text {HB.S.NOS }}, \gamma<15, \mathrm{R}^{2}=0.94\right)$.

The oxygen consumption rate is a measured variable in all experiments from Scenario C, and in the NDHA model structure it is the sum of several processes: nitritation, nitratation, heterotrophic aerobic growth, decay and hydrolysis. The experimental design allowed the independent and sequential estimation of the interferences of these processes on AOB activity (Table 2). First, the substrate affinity and maximum growth rate of $\mathrm{NO}_{2}^{-}$oxidation $\left(K_{N O B . H N O 2}, \mu_{N O B}\right)$ were estimated $(\gamma<7)$. Then, $\mathrm{NH}_{4}^{+}$oxidation was described by estimating the substrate affinity and maximum growth rate of the first nitritation step $\left(K_{A O B . N H 3}, \mu_{A O B . A M O}\right)$. The NDHA model considers $\mathrm{NH}_{3}$ as true substrate for $\mathrm{AOB}$, and at lower $\mathrm{pH}$ levels $\mathrm{NH}_{3}$ oxidation slows down, increasing the information content of the experiment compared to the same $\mathrm{NH}_{4}{ }^{+}-\mathrm{N}$ pulse at higher $\mathrm{pH}$. Hence, the ammonia affinity for AOB $\left(K_{A O B . N H 3}=7 \mu \mathrm{gN} / \mathrm{L}\right)$ could be estimated from $\mathrm{NH}_{4}{ }^{+}$pulses $(2-3$ $\mathrm{mgN} / \mathrm{L}$ ) at low $\mathrm{pH}$ as the DO sensitivity to changes in $K_{A O B . N H 3}$ increases at lower $\mathrm{pH}$ levels (S-III). 
After heterotrophic denitrification, nitrite oxidation, and ammonium oxidation had resulted in a good fit, parameters associated to AOB-driven $\mathrm{N}_{2} \mathrm{O}$ production were estimated from $\mathrm{NO}$ and $\mathrm{N}_{2} \mathrm{O}$ data. The contribution of the $\mathrm{NN}$ pathway was estimated from the isolated $\mathrm{N}_{2} \mathrm{O}$ production during $\mathrm{NH}_{4}{ }^{+}$oxidation at high DO, as $\mathrm{N}_{2} \mathrm{O}$ and $\mathrm{NO}$ were mostly sensitive to parameters associated to the NN pathway $\left(\varepsilon_{A O B}, \eta_{N O R}\right)$ (Figure 3, S-III). The NO and $\mathrm{N}_{2} \mathrm{O}$ production observed at the onset of anoxia during $\mathrm{NH}_{4}{ }^{+}$oxidation would correspond to the combined ND and HD contributions (Figure 2C,D). Hence, from experiments in Scenario $\mathrm{C}$ parameters describing the NN and ND pathways, $\varepsilon_{A O B}, \eta_{N I R}$ and $\eta_{N O R}$, could be identified $\left(\gamma_{\text {NO,N2O }}<15\right)$.
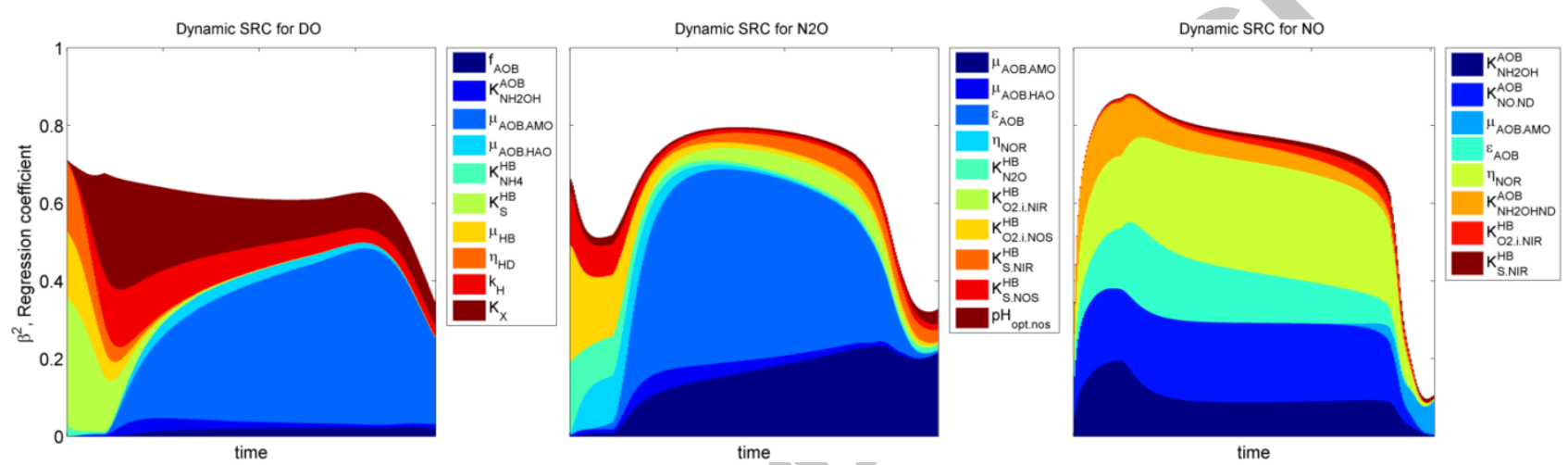

Figure 3 - Dynamic sensitivity analysis (SRC method) of the measured species in experiments (C) after a $\mathrm{NH}_{4}{ }^{+}$pulse under aerobic conditions: DO (left), $\mathrm{N}_{2} \mathrm{O}$ (middle) and $\mathrm{NO}$ (right).

Based on the overall good fit of model predictions and experimental data the NDHA model described the dynamics of the measured DO and $\mathrm{N}$-species $\left(\mathrm{R}^{2} \geq 0.94\right.$, F-test $=1$ for $10 / 11$ datasets, $\left.\mathrm{S}-\mathrm{IV}\right)$. A total of 17 parameters were estimated sequentially with bounded approximate confidence regions indicating good identifiability $(\mathrm{CV}<25 \%)$. Almost all the data points were within the $95 \%$ confidence interval of model predictions, considering the uncertainty of all model parameters, which indicates a good model description of the dataset (S-IV).

Table 2 - Best-fit values for the parameters estimated (at $25^{\circ} \mathrm{C}$ ).

\begin{tabular}{|c|c|c|c|c|c|c|c|c|c|c|c|}
\hline $\begin{array}{l}\text { Parame } \\
\text { ter }\end{array}$ & $\begin{array}{l}\text { Unit } \\
\text { s }\end{array}$ & Value & $\begin{array}{l}\text { Sce } \\
\text { n. }\end{array}$ & $\begin{array}{l}\text { Parame } \\
\text { ter }\end{array}$ & Unit & Value & $\begin{array}{l}\text { Sce } \\
\text { n. }\end{array}$ & $\begin{array}{l}\text { Parame } \\
\text { ter }\end{array}$ & $\begin{array}{l}\text { Un } \\
\text { it }\end{array}$ & Value & $\begin{array}{c}\text { Sce } \\
\text { n. }\end{array}$ \\
\hline $\begin{array}{l}\mathrm{pH}_{\text {optnos }} \\
\mathrm{z}\end{array}$ & $(-)$ & $7.9 \pm 0.1$ & (A) & & $\begin{array}{l}\mathrm{mgCO} \\
\mathrm{D} / \mathrm{L} \\
\mathrm{mgCO}\end{array}$ & $4.3 \pm 0.69$ & (B) & $\mu_{\mathrm{NOB}}$ & $d^{-1}$ & $1.51 \pm 0.07$ & (C) \\
\hline $\mathrm{w}_{\mathrm{nos} Z} \mathrm{Z}$ & $\begin{array}{l}(-) \\
\mathrm{mgN}\end{array}$ & $\begin{array}{l}2.2 \pm 0.2 \\
0.078 \pm\end{array}$ & (A) & $\begin{array}{l}\mathrm{R} \\
\mathrm{K}_{\text {HB.S.NO }}\end{array}$ & $\begin{array}{l}\mathrm{D} / \mathrm{L} \\
\mathrm{mgCO}\end{array}$ & $5.3 \pm 0.83$ & (B) & $\mu_{\mathrm{HB}}$ & $\begin{array}{l}d^{-1} \\
(-\end{array}$ & $\begin{array}{l}7.23 \pm 0.16 \\
0.0031 \pm\end{array}$ & (A) \\
\hline $\mathrm{K}_{\mathrm{HB} . \mathrm{N} 2 \mathrm{O}}$ & $/ \mathrm{L}$ & $\begin{array}{l}0.020 \\
1.71 \pm\end{array}$ & (A) & $\begin{array}{l}\mathrm{s} \\
\mathrm{K}_{\text {AOB.NH }}\end{array}$ & $\mathrm{D} / \mathrm{L}$ & $\begin{array}{l}4.1 \pm 0.40 \\
7.00 \pm\end{array}$ & (B) & $\varepsilon_{\mathrm{AOB}}$ & ) & 0.0001 & (C) \\
\hline$\mu_{\text {HB.NAR }}$ & $d^{-1}$ & $\begin{array}{l}0.11 \\
1.11 \pm\end{array}$ & (A) & $\begin{array}{l}3 \\
\mathrm{~K}_{\mathrm{NOB} . \mathrm{HN}}\end{array}$ & $\mu \mathrm{gN} / \mathrm{L}$ & $\begin{array}{l}1.17 \\
0.027 \pm\end{array}$ & (C) & $\eta_{\text {NIR }}$ & ) & $0.22 \pm 0.01$ & (C) \\
\hline$\mu_{\text {HB.NIR }}$ & $\begin{array}{l}d^{-1} \\
d^{-1}\end{array}$ & $\begin{array}{l}0.07 \\
1.17 \pm \\
0.02\end{array}$ & (A) & $\begin{array}{l}\text { O2 } \\
\mu_{\text {AOB.AM }}\end{array}$ & $\mu \mathrm{gN} / \mathrm{L}$ & $\begin{array}{l}0.006 \\
0.86 \pm \\
0.02\end{array}$ & (C) & $\eta_{\mathrm{NOR}}$ & ) & $0.36 \pm 0.02$ & (C) \\
\hline
\end{tabular}


Single $\mathrm{NH}_{2} \mathrm{OH}$ pulses were not considered for parameter estimation as the electron flow during $\mathrm{NH}_{2} \mathrm{OH}$ oxidation in the $\mathrm{AOB}$ metabolism differs from that during $\mathrm{NH}_{4}{ }^{+}$oxidation (two out of the four electrons are shuttled back from $\mathrm{HAO}$ to $\mathrm{AMO}$ ). Hence, $\mathrm{NH}_{2} \mathrm{OH}$ pulses are not representative of $\mathrm{NH}_{4}{ }^{+}$-oxidation driven $\mathrm{N}_{2} \mathrm{O}$ production. Also, the contribution of $\mathrm{NH}_{2} \mathrm{OH}$ to abiotic $\mathrm{NO} / \mathrm{N}_{2} \mathrm{O}$ production was not significant after $\mathrm{NH}_{2} \mathrm{OH}$ pulses for experiments in Scenario C (S-V).

The analysis of residuals from best-fit simulations after parameter estimation with the complete datasets showed a high autocorrelation of the residuals for some experiments. The DO and $\mathrm{N}_{2} \mathrm{O}$ datasets were downsampled by lowering the data acquisition frequency down to non-autocorrelated values $[25,28]$. In Scenario $\mathrm{C}$, the DO dataset used to estimate the parameter subset $K_{A O B . N H 3}$ and $\mu_{A O B . A M O}$ was down-sampled thirteenfold to correct autocorrelation (from 1230 to 96 data points). With the updated dataset the best-fit estimates did not change significantly ( 0.7 and $4.2 \%$ variation between datasets), but the uncertainty increased almost four-fold (S-IV).

\subsection{Model validation}

The predictive ability of the calibrated NDHA model was evaluated on a different set of batch experiments where the AS biomass from the same WWTP was subject to varying N pulses under constant aeration [35]. The model was evaluated with the calibrated parameter set in Scenarios D and E against DO, $\mathrm{NH}_{4}{ }^{+}, \mathrm{NO}_{2}{ }^{-}$and $\mathrm{N}_{2} \mathrm{O}$ data. Only the oxygen mass transfer coefficient $\left(k_{L} a_{O 2}\right)$ was tuned as the aeration in the respirometric assays from Scenarios A, B, C was null. Overall, the model captured the trends of DO, main N-species and liquid $\mathrm{N}_{2} \mathrm{O}$ without modifying any parameter value $\left(\mathrm{R}_{\text {avg }}^{2}\right.$ for $\mathrm{DO}=0.98 ; \mathrm{NH}_{4}^{+}=0.99 ; \mathrm{NO}_{2}^{-}=0.84 ; \mathrm{N}_{2} \mathrm{O}=$ $0.80)$, and only the $\mathrm{N}_{2} \mathrm{O}$ residuals $\left(y_{s i m, i}-y_{o b s, i}\right)$ did not pass the more rigorous F-distribution test $\left(\mathrm{F}_{\mathrm{N} 2 \mathrm{O}}=0\right)$ (Figure 4). 

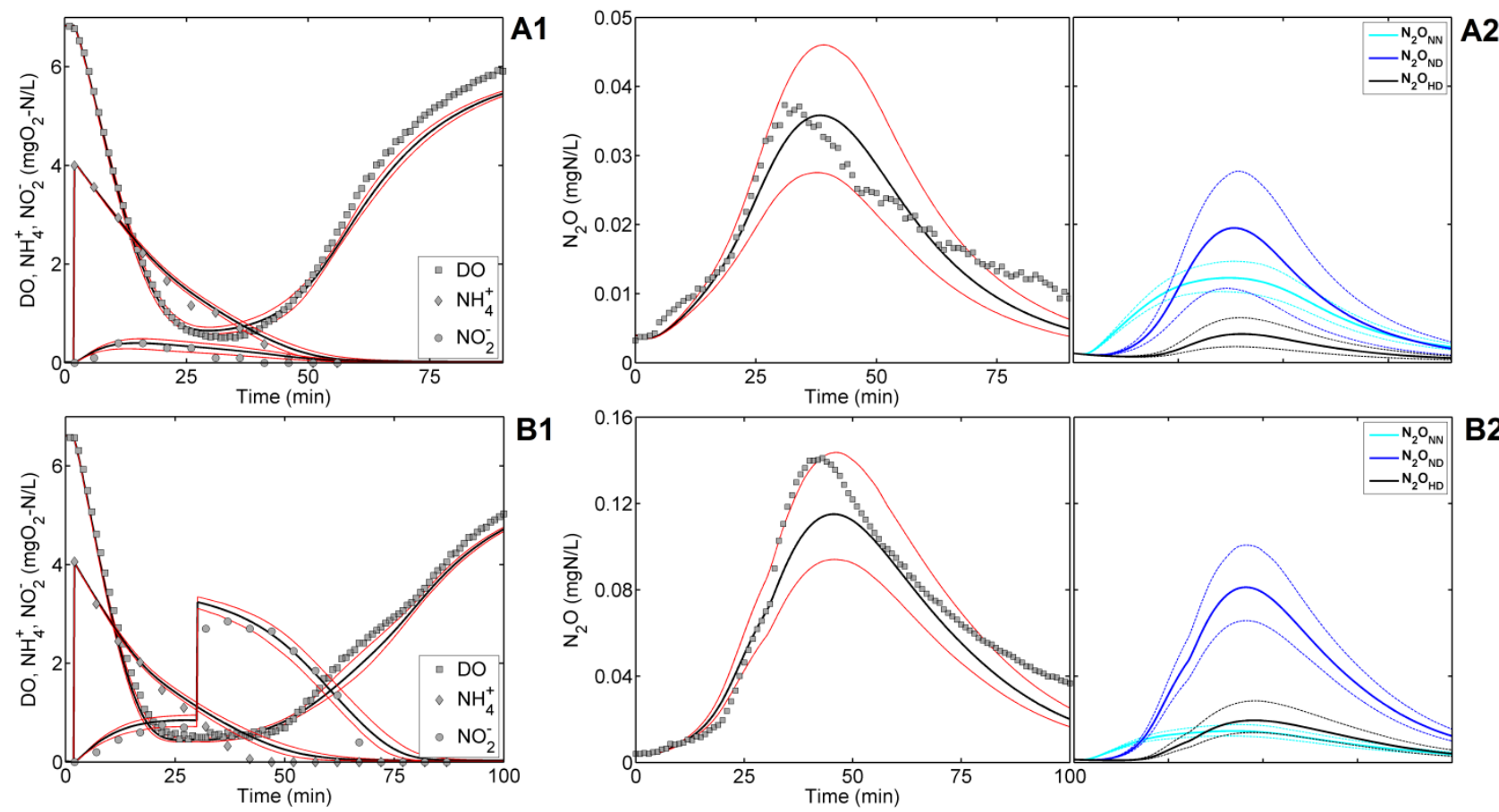

B1

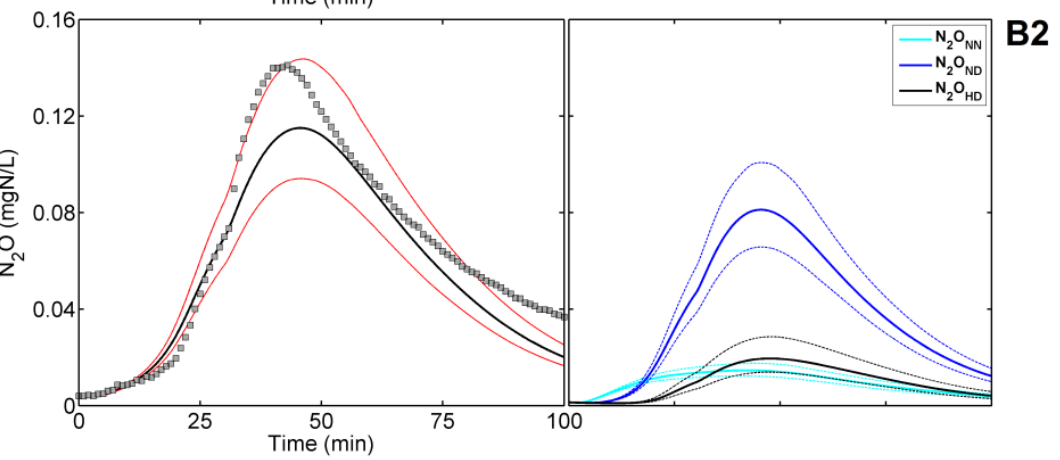

Figure 4-Model validation results from Scenario D. Effect of $\mathrm{NO}_{3}^{-}$pulse $(\mathrm{A} 1, \mathrm{~A} 2)$ and $\mathrm{NO}_{2}{ }^{-}$pulse $(\mathrm{B} 1, \mathrm{~B} 2)$ during aerobic $\mathrm{NH}_{4}{ }^{+}$oxidation. Main substrates: $\mathrm{DO}, \mathrm{NH}_{4}{ }^{+}, \mathrm{NO}_{2}{ }^{-}$(A1, B1), $\mathrm{N}_{2} \mathrm{O}$ and $\mathrm{N}_{2} \mathrm{O}$ pathway contributions (A2, B2). Experimental results (markers), best-fit simulations (black lines), 95\% confidence intervals (red lines). Nitrifier nitrification (cyan), nitrifier denitrification (blue), and heterotrophic denitrification (black) pathway contributions; mean (solid lines) and 95\% confidence intervals (dashed lines). Confidence intervals of uncertainty from the estimated parameters only (Table 2).

The model predicts a higher $\mathrm{N}_{2} \mathrm{O}$ fraction with increasing $\mathrm{NH}_{4}{ }^{+}$pulses as $\mathrm{NH}_{4}{ }^{+}$oxidation occurs at low DO for longer periods, thus promoting the contribution of denitrification pathways (Figure 5). In terms of pathway contributions to the total $\mathrm{N}_{2} \mathrm{O}$ pool, the model predicts that after addition of an $\mathrm{NH}_{4}{ }^{+}$pulse at high DO the NN pathway has the largest contribution (Figure 4). When $\mathrm{NO}_{2}{ }^{-}$accumulates in the bulk and DO reaches low concentrations ( $\mathrm{DO}<0.5 \mathrm{mg} / \mathrm{L}$ ), or when $\mathrm{NO}_{2}{ }^{-}$is spiked, the $\mathrm{ND}$ and HD contributions increase. Even though the model predicts a positive $\mathrm{HD}$ pathway contribution to the $\mathrm{N}_{2} \mathrm{O}$ pool (no net $\mathrm{N}_{2} \mathrm{O}$ consumption) it was significantly lower than the ND pathway (Figure 5).

Pulse (mgN/L) $\quad \mathrm{N}_{2} \mathrm{O}$ emission factor $\quad \mathrm{N}_{2} \mathrm{O}$ pathway contribution

\begin{tabular}{|c|c|c|c|c|c|c|c|}
\hline Scen. & $\mathrm{NH}_{4}^{+}$ & $\mathrm{NO}_{2}^{-}$ & $\mathrm{NO}_{3}^{-}$ & $\mathrm{N}_{2} \mathrm{O} / \mathrm{NH}_{4, \mathrm{rem}}$ & NN (\%) & ND (\%) & $\mathrm{HD}(\%)$ \\
\hline D-1 & 2.3 & \multirow{7}{*}{2.5} & \multirow{7}{*}{2.0} & $0.6 \%$ & $57 \%$ & $33 \%$ & $10 \%$ \\
\hline D-2 & 3.6 & & & $1.7 \%$ & $22 \%$ & $57 \%$ & $21 \%$ \\
\hline D-3 & 4.7 & & & $2.5 \%$ & $19 \%$ & $60 \%$ & $21 \%$ \\
\hline D-4 & 5.5 & & & $3.2 \%$ & $13 \%$ & $64 \%$ & $23 \%$ \\
\hline E-1 & 3.9 & & & $0.8 \%$ & $43 \%$ & $44 \%$ & $13 \%$ \\
\hline E-2 & 4.0 & & & $0.8 \%$ & $41 \%$ & $47 \%$ & $12 \%$ \\
\hline$E-3$ & 4.1 & & & $1.7 \%$ & $17 \%$ & $66 \%$ & $17 \%$ \\
\hline
\end{tabular}


Figure 5 - Model evaluation results for continuously aerated batch tests for different $\mathrm{NH}_{4}^{+}, \mathrm{NO}_{2}^{-}, \mathrm{NO}_{3}^{-}$pulse additions: $\mathrm{N}_{2} \mathrm{O}$ emission factor and $\mathrm{N}_{2} \mathrm{O}$ pathway contributions.

\subsection{Model evaluation and uncertainty of $\mathbf{N 2 O}$ emissions during N-removal}

$\mathrm{N}_{2} \mathrm{O}$ emissions from $\mathrm{AS}$ biomass during aerobic $\mathrm{NH}_{4}{ }^{+}$oxidation simulations with best-fit estimate parameters were predicted for a wider range of $\mathrm{DO}(0.2-4 \mathrm{mg} / \mathrm{L})$ and $\mathrm{NO}_{2}^{-}(0-1.4 \mathrm{mgN} / \mathrm{L})$ at excess $\mathrm{NH}_{4}{ }^{+}$. The $\mathrm{N}_{2} \mathrm{O}$ emission factor and individual pathway contributions to the total $\mathrm{N}_{2} \mathrm{O}$ pool at pseudo-steady state are shown in Figure 6. The NN pathway contributes most at the lowest $\mathrm{NO}_{2}{ }^{-}$and highest $\mathrm{DO}(98 \%)$, and the least at high $\mathrm{NO}_{2}^{-}$and low DO (3\%). The ND and HD pathways showed similar trends and opposite compared to the NN pathway, with maximum contributions of $72 \%$ and $43 \%$ respectively. The $\mathrm{N}_{2} \mathrm{O}$ emission factor ranged between 0.45 and $12.3 \%$ with a very sharp increase towards low DO and high $\mathrm{NO}_{2}^{-}$. For example, at $\mathrm{DO}=2 \mathrm{mg} / \mathrm{L}$, with increasing $\mathrm{NO}_{2}{ }^{-}$concentrations the emission factor increased from 0.45 to $1.26 \%$.
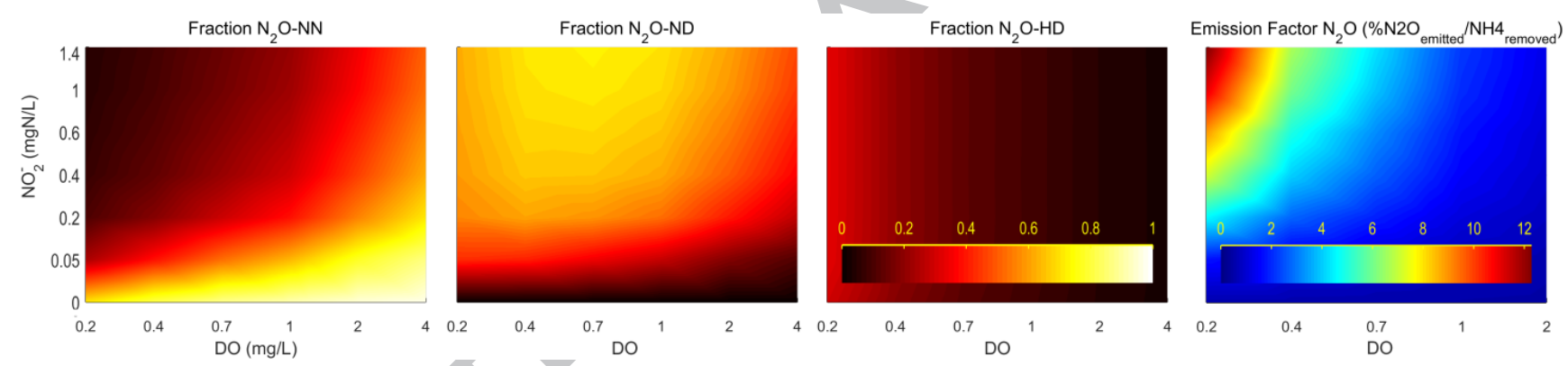

Figure 6 - Model evaluation at varying $\mathrm{NO}_{2}{ }^{-}$and $\mathrm{DO}$ concentrations during excess $\mathrm{NH}_{4}{ }^{+}$removal $(\mathrm{pH}=7.2)$. From left to right: Pathway contributions to total $\mathrm{N}_{2} \mathrm{O}$ pool NN, ND, $\mathrm{HD} ; \mathrm{N}_{2} \mathrm{O}$ emission factor.

The uncertainty in prediction of $\mathrm{N}$-removing processes propagates into prediction of $\mathrm{N}_{2} \mathrm{O}$ production, increasing the uncertainty of $\mathrm{N}_{2} \mathrm{O}$ emissions compared to main $\mathrm{N}$-species (Figure 4). Here, the precision of the biological parameter estimates from respirometric assays the uncertainty of $\mathrm{N}_{2} \mathrm{O}$ emissions in the nitrification/denitrification case study (low and high DO) was evaluated [42]. Two cases were analysed: the calibrated parameter subset with the estimated uncertainty from Table 2, and using uncertainty classes as a reference (S-II). By comparing the two cases the uncertainty calculated from Table 2 was only $28 \%$ of that simulated with the reference. The calibrated NDHA model predicted for low and high DO an $\mathrm{N}_{2} \mathrm{O}$ emission factor of $4.6 \pm 0.6 \%$ and $1.2 \pm 0.1 \%$, which corresponds to low coefficients of variation of the emission factors (9 and 12\%) (Figure 7). Similarly, the uncertainty of the contributions from each biological pathway was low, indicating precise parameter estimates $\left(\mathrm{CV}_{\mathrm{NN}}=8 \%, \mathrm{CV}_{\mathrm{ND}}=6 \%, \mathrm{CV}_{\mathrm{HD}}=19 \%\right)$.

\section{Discussion}




\subsection{N-dynamics in respirometric assays: experimental and modelling results}

Under endogenous conditions the lowest denitrification rate corresponded to $\mathrm{NO}_{3}{ }^{-}$reduction, followed by $\mathrm{NO}_{2}{ }^{-}$and $\mathrm{N}_{2} \mathrm{O}$ reductions (Figure 1). A limiting electron flow could explain these differences as more reduced $\mathrm{NO}_{\mathrm{x}}{ }^{-}$compounds require fewer electrons to produce $\mathrm{N}_{2}$. To avoid a biased denitrification rate due to a single carbon source [48], a mixture of three carbon sources was considered representative of a complex wastewater ( $20 \%$ formate, $40 \%$ acetate, $40 \%$ propionate COD-based) as the estimated $\mu_{H B}$ value deviated $21 \%$ from the original literature value $\left(5.2\right.$ vs. $\left.6.2 \mathrm{~d}^{-1}\right)$ [41]. Overall, the denitrification rates observed were in the low range of literature values $(\mathbf{S}-\mathbf{V})$. The maximum reduction rate corresponded to NO, which agrees with the low $\mathrm{NO}$ accumulation levels observed during denitrification, followed by $\mathrm{NO}_{3}^{-}, \mathrm{N}_{2} \mathrm{O}$ and $\mathrm{NO}_{2}^{-}$. The differences in the carbon usage by each reduction step can be linked to the high modularity of the heterotrophic denitrifying community [49]. The highest affinity for the electron donor corresponds to $\mathrm{N}_{2} \mathrm{O}$, and lowers for $\mathrm{NO}_{2}{ }^{-}, \mathrm{NO}_{3}{ }^{-}$and $\mathrm{NO}$, similarly to other calibrated denitrification models [50]. After model fitting, the reduction factors for the denitrification steps compared to the aerobic growth rate are similar to reported values.

$\mathrm{N}_{2} \mathrm{O}$ is typically found at very low concentrations due to stripping and/or simultaneous production/consumption processes. Hence, the only biological $\mathrm{N}_{2} \mathrm{O}$ consumption process could be isolated by only providing $\mathrm{N}_{2} \mathrm{O}$ at high concentrations as the only $\mathrm{N}$-source $(>1 \mathrm{mgN} / \mathrm{L})$. pH changes significantly affected the maximum $\mathrm{N}_{2} \mathrm{O}$ consumption rate, in a similar fashion to that found by Pan et al., (2012) for a methanol-fed denitrifying culture, and for a pure culture of Paracoccus denitrificans [52]. By including a sinusoidal function the model captured this trend (Figure 1B). The substrate affinity was independently estimated as $\mu_{H B . N O S}$ had been previously fixed $\left(K_{H B . N 2 O}=0.078 \mathrm{mgN} / \mathrm{L}\right)$ and, differently from Pan et al., (2012), the individual $K_{H B . N 2 O}$ values estimated from each experiment did not correlate with $\mathrm{pH}\left(\mathrm{R}^{2}=0.06, \mathrm{n}\right.$ $=12, \mathbf{S}-\mathbf{I V}$ ). Liquid $\mathrm{N}_{2} \mathrm{O}$ concentrations are commonly measured at similar or lower values than $K_{H B . N 2 O}$, indicating that $\mathrm{N}_{2} \mathrm{O}$ consumption is a substrate limited process and specific experiments must be designed to estimate it [19,53].

AOB-driven $\mathrm{N}_{2} \mathrm{O}$ production is described by three processes whose maximum specific rates are reduction factors for $\mathrm{NH}_{2} \mathrm{OH}$ oxidation $\left(\mu_{A O B . H A O}\right)$. The three reduction factors could be estimated: $\varepsilon_{A O B}(\mathrm{NN}), \eta_{N I R}(\mathrm{ND})$ and $\eta_{N O R}(\mathrm{NN}+\mathrm{ND})$. Direct comparison of the estimated values to other studies is not possible due to differences in model structure. However, $\varepsilon_{A O B}(0.0031)$ and $\eta_{N I R}(0.22)$ were in the same range of other reduction factors from 2-pathway AOB models $\left(\eta_{N N}=0.0007-0.12, \eta_{N I R}=0.03-0.48\right)(\mathbf{S}-\mathbf{I})$.

Moreover, the respirometric experimental design benefited from NO measurements compared to only $\mathrm{N}_{2} \mathrm{O}$ measurements as it allowed: (1) identification of specific parameters (e.g. $K_{H B . S . N I R}$ ) and (2) lowering the estimated uncertainty of $\varepsilon_{A O B}$ and $\eta_{N O R} 4$ and 9-fold respectively (S-IV-1). 


\subsection{Applicability of the NDHA model to mixed liquor biomass: pathway contributions and uncertainty analysis.}

The nitrification/denitrification cycle was re-evaluated with the newly estimated parameters to study the pathway contributions and the uncertainty associated to $\mathrm{N}_{2} \mathrm{O}$ emissions. Almost all the $\mathrm{N}_{2} \mathrm{O}$ was emitted during the aerated phase, as during the anoxic phase $\mathrm{N}_{2} \mathrm{O}$ was consumed with excess COD. The simulated cycle at low DO yielded a higher $\mathrm{N}_{2} \mathrm{O}$ emission factor as compared to that at higher DO (4.6 and 1.2\% respectively), in agreement with other SND systems $[13,54]$. The $\mathrm{N}_{2} \mathrm{O}$ emission factors are comparable with those reported by Wunderlin et al. (2012) after $\mathrm{NH}_{4}{ }^{+}$pulses at the same DO levels (3.8 and 2\%). Also, in a full-scale activated sludge plant the emission factor varied between 0.69 and $3.5 \%$ for a range of DO and $\mathrm{NO}_{2}{ }^{-}$conditions [56].

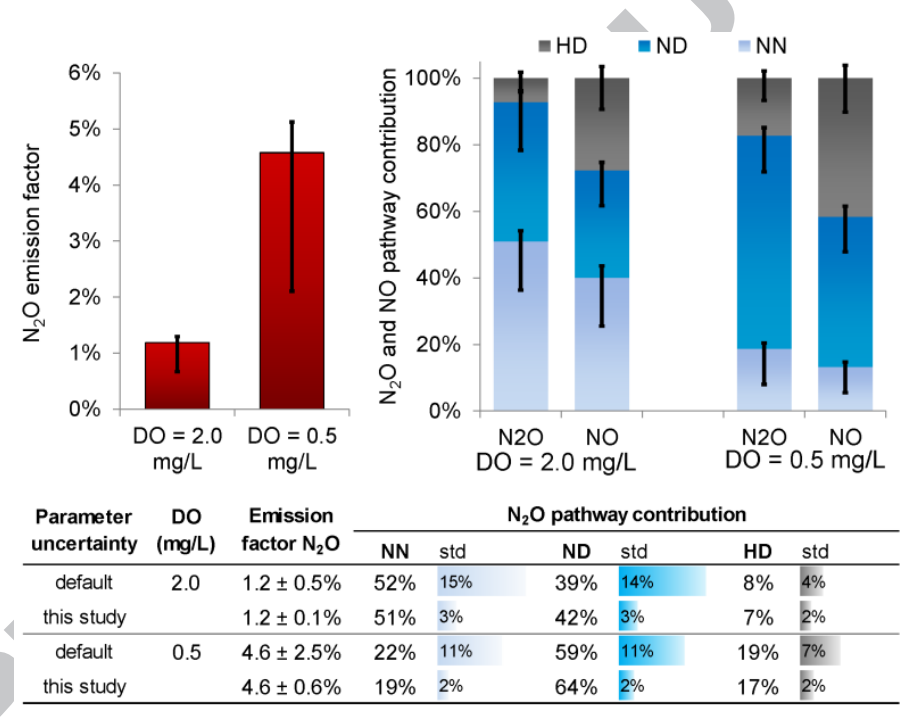

Figure 7 - Nitrification/Denitrification case study after model calibration: $\mathrm{N}_{2} \mathrm{O}$ emission factor (left) and $\mathrm{N}_{2} \mathrm{O}$ and $\mathrm{NO}$ pathway contribution (right). The error bars correspond to the standard deviation of the uncertainty from estimated parameters: (top bar) in this study (Table 2), (bottom bar) default, $\mathrm{n}=500$.

The contribution of the NN pathway increased with DO, while the two denitrification pathways, ND and HD, decreased (Figure 7). For both DO levels the ND contribution was significantly larger than the HD contribution (64 vs 17\%, 42 vs $7 \%$ respectively). Similarly, in other modelling studies an anaerobic/oxic/anoxic process showed that at DO $<1 \mathrm{mg} / \mathrm{L}$ the ND pathway was also the main contributor to the total $\mathrm{N}_{2} \mathrm{O}$ pool, followed by $\mathrm{NN}$ and $\mathrm{HD}$ [57]. However, based on experimental observations other studies predicted a higher HD contribution compared to ND [11,55]. Separating the ND and HD contributions from $\mathrm{NH}_{4}{ }^{+}$oxidation processes with AS biomass is not trivial [35]. Even at minimum C/N ratios the high heterotrophic abundance compensates for the low electron donor concentrations, yielding similar ND and $\mathrm{HD}$ rates, both increasing with $\mathrm{NO}_{2}{ }^{-}$and low DO concentrations. Here, as compared to other 
studies, the step-wise and independent calibration of the three pathways provides more confidence in the model simulations.

During the past years sequential $\mathrm{N}_{2} \mathrm{O}$ dynamic modelling efforts have focused on improving model structures to capture the variety of $\mathrm{N}_{2} \mathrm{O}$ production phenomena and rates observed during wastewater treatment operations. From single to double AOB pathways, and in combination with $\mathrm{HB}, \mathrm{N}_{2} \mathrm{O}$ models have increased in complexity (i.e. more processes and parameters) and improved in their best-fit capabilities. The confidence of model predictions is addressed in WWTP models to assess the risk of excessive effluent nutrient concentrations, but has not been studied for $\mathrm{N}_{2} \mathrm{O}$ models. In our previous study for an AOB-enriched biomass, the calibrated NDHA model showed an $8 \%$ variation of the $\mathrm{N}_{2} \mathrm{O}$ emission factor when only the estimated parameters were considered, but $40 \%$ when all the model parameters were considered uncertain [25]. In this study, the uncertainty was $11 \%$ and $38 \%$ respectively, which would propagate to the carbonfootprint uncertainty of the process. While these results highlight the importance of evaluating the uncertainty of biological parameter estimates in $\mathrm{N}_{2} \mathrm{O}$ emissions, only two other studies are available [25,31]. We believe that future comparison of best-fit simulations and uncertainty results (e.g. 95\% CI) will improve calibration procedures for $\mathrm{N}_{2} \mathrm{O}$ models.

\subsection{Biological realism of $\mathrm{N}$-dynamics during $\mathrm{N}_{2} \mathrm{O}$ model calibration}

\subsubsection{Role of nitric oxide on $\mathrm{N}_{2} \mathrm{O}$ models}

Models with similar $\mathrm{N}_{2} \mathrm{O}$ pathway structures cannot be discriminated only with $\mathrm{N}_{2} \mathrm{O}$ datasets, and additional measurements such as $\mathrm{NO}$ can improve model discrimination [58]. However, only a few $\mathrm{N}_{2} \mathrm{O}$ models have been tested against $\mathrm{NO}$ [22]. In this study net $\mathrm{NO}$ and $\mathrm{N}_{2} \mathrm{O}$ production from $\mathrm{NH}_{4}{ }^{+}$oxidation under aerobic conditions was significantly lower than at the onset of anoxia (Figure 2), as was also reported for pure AOB cultures and nitrifying systems $[3,19,55]$. The higher anoxic rates can be explained by the transient accumulation of $\mathrm{NH}_{2} \mathrm{OH}$, which has been suggested to act as electron donor for $\mathrm{NO}_{2}{ }^{-}$reduction to $\mathrm{N}_{2} \mathrm{O}$ in a two-step process over NO [7,8,59]. The accumulation of NO at low DO and anoxic conditions was also confirmed by an increase in the transcription of the nirK gene in a N. europaea pure culture [6], which highlights the importance of $\mathrm{N}_{2} \mathrm{O}$ models including $\mathrm{NO}$ as an intermediate of the ND pathway. Still, some $\mathrm{N}_{2} \mathrm{O}$ models simplify the ND pathway by direct $\mathrm{NO}_{2}{ }^{-}$reduction to $\mathrm{N}_{2} \mathrm{O}[23,24]$, while in the HD pathway $\mathrm{NO}_{2}{ }^{-}$is reduced to $\mathrm{N}_{2} \mathrm{O}$ over $\mathrm{NO}$ [31]. These model structures would associate $\mathrm{NO}$ production during $\mathrm{NH}_{4}{ }^{+}$ removal at low DO fully to the HD pathway (Figure 2), therefore underestimating the contribution of the ND pathway.

The ratio between the substrate affinity of $\mathrm{NO}$ reductases, $K_{A O B . N O} / K_{H B . N O}$, is an important parameter of $\mathrm{N}_{2} \mathrm{O}$ models as it can shift the predicted contributions of the ND and HD pathways for the same overall $\mathrm{N}_{2} \mathrm{O}$ fit [35]. However, direct estimation of $\mathrm{NO}$ affinity is difficult due to cellular toxicity [60]. In $\mathrm{N}_{2} \mathrm{O}$ models $K_{N O}$ 
values are typically assumed [41,61] and, when estimated, no identifiability metrics are reported [62]. This could partially explain the high variability of reported $\mathrm{NO}$ affinities and $K_{A O B . N O} / K_{H B . N O}$ ratios considered in literature $\left(K_{H B . N O}=0.00015-0.05 \mathrm{mgN} / \mathrm{L}\right.$ and $\left.K_{A O B . N O}, 0.004-1 \mathrm{mgN} / \mathrm{L}, K_{A O B . N O} / K_{H B . N O}=1-56\right)[22,41,50,62-$ 64]. For example, in the study by Wang et al. (2016) the HD pathway has an NO affinity over 50 times higher than the NN pathway. The HD pathway could theoretically uptake NO produced by the NN pathway at a much higher rate and could underestimate the $\mathrm{NN}$ contribution to the total $\mathrm{N}_{2} \mathrm{O}$ pool. Based on current lack of knowledge and to avoid a preferential NO-consumption/ $\mathrm{N}_{2} \mathrm{O}$-production pathway the $\mathrm{NO}$ affinity of $\mathrm{AOB}$ and $\mathrm{HB}$ was set equal.

\subsubsection{Role of hydroxylamine on $\mathrm{N}_{2} \mathrm{O}$ models}

$\mathrm{NH}_{2} \mathrm{OH}$ is an important intermediate in the 2-step $\mathrm{NH}_{4}{ }^{+}$oxidation to $\mathrm{NO}_{2}{ }^{-}$as the electron source for the metabolism of AOB. Low $\mathrm{NH}_{2} \mathrm{OH}$ bulk concentrations have been reported in the liquid phase of pure $\mathrm{AOB}$ cultures and nitrifying systems $\left(\mathrm{NH}_{2} \mathrm{OH}<0.2 \mathrm{mgN} / \mathrm{L}\right)[39,65,66]$, indicating a quick turnover of $\mathrm{NH}_{2} \mathrm{OH}$. $\mathrm{N}_{2} \mathrm{O}$ models have adopted the 2-step $\mathrm{NH}_{4}{ }^{+}$oxidation where $\mathrm{NH}_{2} \mathrm{OH}$ is the direct substrate for $\mathrm{NO}$ and $\mathrm{N}_{2} \mathrm{O}$ production $[20,23,24,50,57]$. However, the accuracy of $\mathrm{NH}_{2} \mathrm{OH}$ predictions is not addressed. For more accurate $\mathrm{NH}_{2} \mathrm{OH}$ predictions a faster $\mathrm{HAO}$ process compared to AMO is necessary as it prevents high $\mathrm{NH}_{2} \mathrm{OH}$ accumulations [25]. This is in agreement with the calibrated NDHA model where differently from other models, $\mu_{H A O}>\mu_{A M O}$ and $K_{A O B . \mathrm{NH} 2 \mathrm{OH}}<K_{A O B . N H 4}\left(K_{A O B . \mathrm{NH} 2 \mathrm{OH}}=0.2 \mathrm{mgN} / \mathrm{L}\right.$ this study, $0.7-2.4 \mathrm{mgN} / \mathrm{L}$ $[20,23,24,50,57])$. The NDHA model predicted average $\mathrm{NH}_{2} \mathrm{OH}$ concentrations of $0.15 \pm 0.09 \mathrm{mgN} / \mathrm{L}$ in Scenario C experiments and $0.13 \pm 0.04 \mathrm{mgN} / \mathrm{L}$ in Scenario D experiments, in close agreement with reported $\mathrm{NH}_{2} \mathrm{OH}$ concentrations.

The higher $\mathrm{N}_{2} \mathrm{O}$ yield observed after $\mathrm{NH}_{2} \mathrm{OH}$ pulses compared to other $\mathrm{N}$-species under aerobic conditions is in agreement with other studies $\left(\approx 0.05\right.$ and $0.2 \mathrm{mgN}_{2} \mathrm{O}-\mathrm{N} / \mathrm{gVSS} / \mathrm{h}$ for $\mathrm{NH}_{4}{ }^{+}$and $\left.\mathrm{NH}_{2} \mathrm{OH}\right)[3,40,55,67]$. The NDHA model structure can describe $\mathrm{N}_{2} \mathrm{O}$ production associated to: aerobic $\mathrm{NH}_{4}^{+}$oxidation (S-I, Processes 15), aerobic $\mathrm{NH}_{2} \mathrm{OH}$ oxidation (Processes 3-5), and anoxic $\mathrm{NH}_{2} \mathrm{OH}$ oxidation (Processes 2, 5). However, the metabolism of AOB during aerobic $\mathrm{NH}_{2} \mathrm{OH}$ oxidation in the absence of $\mathrm{NH}_{4}^{+}$is not representative of wastewater treatment operations: when AMO is not active higher electron availability from $\mathrm{NH}_{2} \mathrm{OH}$ oxidation would lead to higher $\mathrm{N}_{2} \mathrm{O}$ yields from $\mathrm{NO}$ and $\mathrm{NO}_{2}^{-}$reduction. Hence, experiments with solely aerobic $\mathrm{NH}_{2} \mathrm{OH}$ additions should not be used to calibrate the $\mathrm{N}_{2} \mathrm{O}$ models describing the NN and ND pathways. Other $\mathrm{N}_{2} \mathrm{O}$ pathways, such as the associated to Cyt $\mathrm{P} 460$, could be responsible for the high $\mathrm{N}_{2} \mathrm{O}$ production observed during $\mathrm{NH}_{2} \mathrm{OH}$ oxidation [5].

The NDHA model does not describe individually all the possible co-occurring $\mathrm{N}_{2} \mathrm{O}$ pathways in the AOB metabolism, but captures the relevant biological $\mathrm{N}_{2} \mathrm{O}$ production associated to wastewater treatment conditions in the NN and ND processes, where $\mathrm{NH}_{4}{ }^{+}$is the $\mathrm{N}$ source. 


\section{Conclusions}

- A global sensitivity analysis-based experimental design allowed the calibration of an $\mathrm{N}_{2} \mathrm{O}$ model during nitrification and denitrification via respirometric techniques.

- The model considering three biological $\mathrm{N}_{2} \mathrm{O}$ production pathways was calibrated and predicted the $\mathrm{NO}$ and $\mathrm{N}_{2} \mathrm{O}$ dynamics at varying $\mathrm{NH}_{4}^{+}, \mathrm{NO}_{2}^{-}$and $\mathrm{DO}$ levels. Parameters from hydrolysis, heterotrophic denitrification, nitrite and ammonia oxidation were identified.

- The calibrated model response indicated autocorrelation of residuals, which was corrected by decreasing the frequency of data acquisition. Yet, a total of 17 parameters could be identified with low confidence intervals $(\mathrm{CV}<25 \%)$.

- The uncertainty of $\mathrm{N}_{2} \mathrm{O}$ model predictions was evaluated during aerobic $\mathrm{NH}_{4}^{+}$oxidation at two different DO levels showing low uncertainty of the $\mathrm{N}_{2} \mathrm{O}$ emission factors $(\mathrm{CV} \leq 12 \%)$.

- Biological $\mathrm{N}_{2} \mathrm{O}$ consumption was highly dependent on $\mathrm{pH}$, described with a sinusoidal function, which helps associating $\mathrm{N}_{2} \mathrm{O}$ dynamics to both changes in $\mathrm{N}_{2} \mathrm{O}$ production and $\mathrm{N}_{2} \mathrm{O}$ consumption.

\section{Software availability}

The MATLAB/SIMULINK code containing the implementation of the model is free upon request to the corresponding author.

\section{Acknowledgements}

This research was funded by the Danish Agency for Science, Technology and Innovation through the Research Project LaGas (12-132633). The authors have no conflict of interest to declare. Dr. Ulf Jeppsson (Lund University) is acknowledged for having provided the codes of the Benchmark Simulation Model no 2 from which this work was developed. 


\section{References}

[1] J.H. Ahn, S. Kim, H. Park, B. Rahm, K. Pagilla, K. Chandran, N2O emissions from activated sludge processes, 2008-2009: results of a national monitoring survey in the United States., Environ. Sci. Technol. 44 (2010) 4505-11. doi:10.1021/es903845y.

[2] Y. Lim, D.-J. Kim, Quantification method of N2O emission from full-scale biological nutrient removal wastewater treatment plant by laboratory batch reactor analysis, Bioresour. Technol. 165 (2014) 111-115. doi:10.1016/j.biortech.2014.03.021.

[3] J.A. Kozlowski, K.D. Kits, L.Y. Stein, Comparison of Nitrogen Oxide Metabolism among Diverse Ammonia-Oxidizing Bacteria, Front. Microbiol. 7 (2016) 1-9. doi:10.3389/fmicb.2016.01090.

[4] J.D. Caranto, K.M. Lancaster, Nitric oxide is an obligate bacterial nitrification intermediate produced by hydroxylamine oxidoreductase, Proc. Natl. Acad. Sci. 114 (2017) 8217-8222. doi:10.1073/pnas.1704504114.

[5] J.D. Caranto, A.C. Vilbert, K.M. Lancaster, Nitrosomonas europaea cytochrome P460 is a direct link between nitrification and nitrous oxide emission, Proc. Natl. Acad. Sci. 113 (2016) 14704-14709. doi:10.1073/pnas.1611051113.

[6] R. Yu, O. Perez-Garcia, H. Lu, K. Chandran, Nitrosomonas europaea adaptation to anoxic-oxic cycling: Insights from transcription analysis, proteomics and metabolic network modeling, Sci. Total Environ. 615 (2018) 1566-1573. doi:10.1016/j.scitotenv.2017.09.142.

[7] P. de Bruijn, A.A. van de Graaf, M.S.M. Jetten, L.A. Robertson, J.G. Kuenen, Growth of Nitrosomonas europaea on hydroxylamine, FEMS Microbiol. Lett. 125 (1995) 179-184.

[8] R.A. Kester, Production of NO and N2O by Pure Cultures of Nitrifying and Denitrifying Bacteria during Changes in Aeration, Appl. Environ. Microbiol. 63 (1997) 3872-3877.

[9] B.C. Berks, S.J. Ferguson, J.W.B. Moir, D.J. Richardson, Enzymes and associated electron transport systems that catalyse the respiratory reduction of nitrogen oxides and oxyanions, Biochim. Biophys. Acta - Bioenerg. 1232 (1995) 97-173. doi:10.1016/0005-2728(95)00092-5.

[10] A.M. Lotito, P. Wunderlin, A. Joss, M. Kipf, H. Siegrist, Nitrous oxide emissions from the oxidation tank of a pilot activated sludge plant., Water Res. 46 (2012) 3563-73. doi:10.1016/j.watres.2012.03.067.

[11] Z. Hu, J. Zhang, H. Xie, S. Li, J. Wang, T. Zhang, Effect of anoxic/aerobic phase fraction on N2O 
emission in a sequencing batch reactor under low temperature, Bioresour. Technol. 102 (2011) 54865491. doi:10.1016/j.biortech.2010.10.037.

[12] W. Jia, S. Liang, J. Zhang, H.H. Ngo, W. Guo, Y. Yan, Y. Zou, Nitrous oxide emission in lowoxygen simultaneous nitrification and denitrification process: Sources and mechanisms., Bioresour. Technol. 136 (2013) 444-51. doi:10.1016/j.biortech.2013.02.117.

[13] G. Tallec, J. Garnier, G. Billen, M. Gousailles, Nitrous oxide emissions from secondary activated sludge in nitrifying conditions of urban wastewater treatment plants: effect of oxygenation level., Water Res. 40 (2006) 2972-80. doi:10.1016/j.watres.2006.05.037.

[14] P. Wunderlin, M.F. Lehmann, H. Siegrist, B. Tuzson, A. Joss, L. Emmenegger, J. Mohn, Isotope signatures of $\mathrm{N} 2 \mathrm{O}$ in a mixed microbial population system: constraints on $\mathrm{N} 2 \mathrm{O}$ producing pathways in wastewater treatment., Environ. Sci. Technol. 47 (2013) 1339-48. doi:10.1021/es303174x.

[15] S. Toyoda, Y. Suzuki, S. Hattori, K. Yamada, A. Fujii, N. Yoshida, R. Kouno, K. Murayama, H. Shiomi, Isotopomer analysis of production and consumption mechanisms of $\mathrm{N} 2 \mathrm{O}$ and $\mathrm{CH} 4$ in an advanced wastewater treatment system., Environ. Sci. Technol. 45 (2011) 917-22. doi:10.1021/es102985u.

[16] C. Leix, J.E. Drewes, L. Ye, K. Koch, Strategies for enhanced deammonification performance and reduced nitrous oxide emissions, Bioresour. Technol. 236 (2017) 174-185. doi:10.1016/j.biortech.2017.03.182.

[17] M.J. Kampschreur, H. Temmink, R. Kleerebezem, M.S.M. Jetten, M.C.M. van Loosdrecht, Nitrous oxide emission during wastewater treatment., Water Res. 43 (2009) 4093-103. doi:10.1016/j.watres.2009.03.001.

[18] Y. Wang, X. Lin, D. Zhou, L. Ye, H. Han, C. Song, Nitric oxide and nitrous oxide emissions from a full-scale activated sludge anaerobic/anoxic/oxic process, Chem. Eng. J. 289 (2016) 330-340. doi:10.1016/j.cej.2015.12.074.

[19] M.J. Kampschreur, N.C.G. Tan, R. Kleerebezem, C. Picioreanu, M.S.M. Jetten, M.C.M. Van Loosdrecht, Effect of dynamic process conditions on nitrogen oxides emission from a nitrifying culture., Environ. Sci. Technol. 42 (2008) 429-35.

[20] B.-J. Ni, L. Ye, Y. Law, C. Byers, Z. Yuan, Mathematical Modeling of Nitrous Oxide (N 2 O) Emissions from Full-Scale Wastewater Treatment Plants, Environ. Sci. Technol. 47 (2013) 77957803. doi:10.1021/es4005398. 
[21] C. Domingo-Félez, A.G. Mutlu, M.M. Jensen, B.F. Smets, Aeration Strategies To Mitigate Nitrous Oxide Emissions from Single-Stage Nitritation/Anammox Reactors, Environ. Sci. Technol. 48 (2014) 8679-8687. doi:10.1021/es501819n.

[22] M. Spérandio, M. Pocquet, L. Guo, B.-J. Ni, P.A. Vanrolleghem, Z. Yuan, Evaluation of different nitrous oxide production models with four continuous long-term wastewater treatment process data series, Bioprocess Biosyst. Eng. 39 (2016) 493-510. doi:10.1007/s00449-015-1532-2.

[23] M. Pocquet, Z. Wu, I. Queinnec, M. Sperandio, A two pathway model for N2O emissions by ammonium oxidizing bacteria supported by the NO/N2O variation, Water Res. 88 (2016) 948-959. doi:10.1016/j.watres.2015.11.029.

[24] B.-J. Ni, L. Peng, Y. Law, J. Guo, Z. Yuan, Modeling of Nitrous Oxide Production by Autotrophic Ammonia-Oxidizing Bacteria with Multiple Production Pathways., Environ. Sci. Technol. 48 (2014) 3916-24. doi:10.1021/es405592h.

[25] C. Domingo-Félez, M. Calderó-Pascual, G. Sin, B.G. Plósz, B.F. Smets, Calibration of the comprehensive NDHA-N 2 O dynamics model for nitrifier-enriched biomass using targeted respirometric assays, Water Res. 126 (2017) 29-39. doi:10.1016/j.watres.2017.09.013.

[26] N.D. Bennett, B.F.W. Croke, G. Guariso, J.H.A. Guillaume, S.H. Hamilton, A.J. Jakeman, S. MarsiliLibelli, L.T.H. Newham, J.P. Norton, C. Perrin, S.A. Pierce, B. Robson, R. Seppelt, A.A. Voinov, B.D. Fath, V. Andreassian, Characterising performance of environmental models, Environ. Model. Softw. 40 (2013) 1-20. doi:10.1016/j.envsoft.2012.09.011.

[27] J.W. Haefner, Modeling Biological Systems: Principles and Applications, Second, Springer, 2005.

[28] K. Cierkens, S. Plano, L. Benedetti, S. Weijers, J. de Jonge, I. Nopens, Impact of influent data frequency and model structure on the quality of WWTP model calibration and uncertainty., Water Sci. Technol. 65 (2012) 233-42. doi:10.2166/wst.2012.081.

[29] L. Peng, B.-J. Ni, L. Ye, Z. Yuan, The combined effect of dissolved oxygen and nitrite on N2O production by ammonia oxidizing bacteria in an enriched nitrifying sludge, Water Res. 73 (2015) 2936. doi:10.1016/j.watres.2015.01.021.

[30] D.J.I. Gustavsson, S. Tumlin, Carbon footprints of Scandinavian wastewater treatment plants, Water Sci. Technol. 68 (2013) 887. doi:10.2166/wst.2013.318.

[31] G. Mannina, A. Cosenza, G. Viviani, G.A. Ekama, Sensitivity and uncertainty analysis of an integrated ASM2d MBR model for wastewater treatment, Chem. Eng. J. 351 (2018) 579-588. 
doi:10.1016/j.cej.2018.06.126.

[32] X. Li, L.-K. Ju, Two-Phase Decay of Aerobic Sludge Shown by Online Fluorescence and Modeled with Interaction of Heterotrophs and Nitrifiers, Environ. Eng. Sci. 19 (2002) 79-87. doi:10.1089/10928750252953714.

[33] A.A. Van De Graaf, P. De Bruijn, L.A. Robertson, M.S.M. Jetten, J.G. Kuenen, Autotrophic growth of anaerobic am monium-oxidizing microorganisms in a fluidized bed reactor, Microbiology. 142 (1996) 2187-2196.

[34] APHA, AWWA, WEF, Standard Methods for the Examination of Water and Wastewater, 20th ed., Washington DC, 1999.

[35] C. Domingo-Félez, C. Pellicer-Nàcher, M.S. Petersen, M.M. Jensen, B.G. Plósz, B.F. Smets, Heterotrophs are key contributors to nitrous oxide production in activated sludge under low C-to-N ratios during nitrification-Batch experiments and modeling, Biotechnol. Bioeng. 114 (2017) 132-140. doi:10.1002/bit.26062.

[36] K. Chandran, Z. Hu, B.F. Smets, A critical comparison of extant batch respirometric and substrate depletion assays for estimation of nitrification biokinetics, Biotechnol. Bioeng. 101 (2008) 62-72. doi:10.1002/bit.21871.

[37] H. Brouwer, A. Klapwijk, K.J. Keesman, Identification of activated sludge and wastewater characteristics using respirometric batch-experiments, Water Res. 32 (1998) 1240-1254. doi:10.1016/S0043-1354(97)00334-5.

[38] C. Domingo-Félez, B.F. Smets, A consilience model to describe N 2 O production during biological N removal, Environ. Sci. Water Res. Technol. 2 (2016) 923-930. doi:10.1039/C6EW00179C.

[39] A. Soler-Jofra, B. Stevens, M. Hoekstra, C. Picioreanu, D. Sorokin, M.C.M. van Loosdrecht, J. Pérez, Importance of abiotic hydroxylamine conversion on nitrous oxide emissions during nitritation of reject water, Chem. Eng. J. 287 (2016) 720-726. doi:10.1016/j.cej.2015.11.073.

[40] A. Terada, S. Sugawara, K. Hojo, Y. Takeuchi, S. Riya, W.F. Harper, T. Yamamoto, M. Kuroiwa, K. Isobe, C. Katsuyama, Y. Suwa, K. Koba, M. Hosomi, Hybrid Nitrous Oxide Production from a Partial Nitrifying Bioreactor: Hydroxylamine Interactions with Nitrite, Environ. Sci. Technol. 51 (2017) 2748-2756. doi:10.1021/acs.est.6b05521.

[41] W.C. Hiatt, C.P.L. Grady, An updated process model for carbon oxidation, nitrification, and denitrification., Water Environ. Res. 80 (2008) 2145-2156. doi:10.2175/106143008X304776. 
[42] G. Sin, K. V Gernaey, M.B. Neumann, M.C.M. van Loosdrecht, W. Gujer, Uncertainty analysis in WWTP model applications: a critical discussion using an example from design., Water Res. 43 (2009) 2894-906. doi:10.1016/j.watres.2009.03.048.

[43] F. Campolongo, A. Saltelli, Sensitivity analysis of an environmental model: an application of different analysis methods, Reliab. Eng. Syst. Saf. 57 (1997) 49-69. doi:10.1016/S09518320(97)00021-5.

[44] R. Brun, M. Kühni, H. Siegrist, W. Gujer, P. Reichert, Practical identifiability of ASM2d parameters-systematic selection and tuning of parameter subsets., Water Res. 36 (2002) 4113-27.

[45] E.M.L. Beale, Confidence Regions in Non-Linear Estimation, J. R. Stat. Soc. Ser. B-Statistical Methodol. 22 (1960) 41-88. doi:10.2307/2983877.

[46] F. Garcia-Ochoa, E. Gomez, Bioreactor scale-up and oxygen transfer rate in microbial processes: an overview., Biotechnol. Adv. 27 (2009) 153-76. doi:10.1016/j.biotechadv.2008.10.006.

[47] S. Park, W. Bae, J. Chung, S.-C. Baek, Empirical model of the pH dependence of the maximum specific nitrification rate, Process Biochem. 42 (2007) 1671-1676.

doi:10.1016/j.procbio.2007.09.010.

[48] H. Lu, K. Chandran, D. Stensel, Microbial ecology of denitrification in biological wastewater treatment, Water Res. 64 (2014) 237-254. doi:10.1016/j.watres.2014.06.042.

[49] D.R.H. Graf, C.M. Jones, S. Hallin, Intergenomic Comparisons Highlight Modularity of the Denitrification Pathway and Underpin the Importance of Community Structure for N2O Emissions, PLoS One. 9 (2014) e114118. doi:10.1371/journal.pone.0114118.

[50] B.-J. Ni, M. Ruscalleda, C. Pellicer-Nàcher, B.F. Smets, Modeling nitrous oxide production during biological nitrogen removal via nitrification and denitrification: extensions to the general ASM models., Environ. Sci. Technol. 45 (2011) 7768-76. doi:10.1021/es201489n.

[51] Y. Pan, L. Ye, B.-J. Ni, Z. Yuan, Effect of $\mathrm{pH}$ on $\mathrm{N}_{2} \mathrm{O}$ reduction and accumulation during denitrification by methanol utilizing denitrifiers., Water Res. 46 (2012) 4832-40. doi:10.1016/j.watres.2012.06.003.

[52] L. Bergaust, Y. Mao, L.R. Bakken, Å. Frostegård, Denitrification response patterns during the transition to anoxic respiration and posttranscriptional effects of suboptimal ph on nitrogen oxide reductase in paracoccus denitrificans, Appl. Environ. Microbiol. 76 (2010) 6387-6396. doi:10.1128/AEM.00608-10. 
[53] E. Lindblom, M. Arnell, X. Flores-Alsina, F. Stenström, D.J.I. Gustavsson, J. Yang, U. Jeppsson, Dynamic modelling of nitrous oxide emissions from three Swedish sludge liquor treatment systems, Water Sci. Technol. 73 (2015) wst2015534. doi:10.2166/wst.2015.534.

[54] Z. Hu, J. Zhang, S. Li, H. Xie, J. Wang, T. Zhang, Y. Li, H. Zhang, Effect of aeration rate on the emission of $\mathrm{N} 2 \mathrm{O}$ in anoxic-aerobic sequencing batch reactors (A/O SBRs)., J. Biosci. Bioeng. 109 (2010) 487-91. doi:10.1016/j.jbiosc.2009.11.001.

[55] P. Wunderlin, J. Mohn, A. Joss, L. Emmenegger, H. Siegrist, Mechanisms of N2O production in biological wastewater treatment under nitrifying and denitrifying conditions., Water Res. 46 (2012) 1027-37. doi:10.1016/j.watres.2011.11.080.

[56] B.-J. Ni, Y. Pan, B. van den Akker, L. Ye, Z. Yuan, Full-Scale Modeling Explaining Large Spatial Variations of Nitrous Oxide Fluxes in a Step-Feed Plug-Flow Wastewater Treatment Reactor, Environ. Sci. Technol. 49 (2015) 9176-9184. doi:10.1021/acs.est.5b02038.

[57] X. Ding, J. Zhao, B. Hu, Y. Chen, G. Ge, X. Li, S. Wang, K. Gao, X. Tian, Mathematical modeling of nitrous oxide production in an anaerobic/oxic/anoxic process, Bioresour. Technol. 222 (2016) 39-48. doi:10.1016/j.biortech.2016.09.092.

[58] L. Lang, M. Pocquet, B.-J. Ni, Z. Yuan, M. Spérandio, Comparison of different two-pathway models for describing the combined effect of DO and nitrite on the nitrous oxide production by ammoniaoxidizing bacteria, Water Sci. Technol. 75 (2017) 491-500. doi:10.2166/wst.2016.389.

[59] M. Poth, D.D. Focht, 15N Kinetic Analysis of N20 Production by Nitrosomonas europaea: an Examination of Nitrifier Denitrification, Appl. Environ. Microbiol. 49 (1985) 1134-1141.

[60] R. Schulthess, W. Gujer, Release of nitrous oxide (N2O) from denitrifying activated sludge: Verification and application of a mathematical model, Water Res. 30 (1996) 521-530.

[61] Y. Pan, B. Ni, Z. Yuan, Modeling electron competition among nitrogen oxides reduction and N2O accumulation in denitrification., Environ. Sci. Technol. 47 (2013) 11083-91. doi:10.1021/es402348n.

[62] F. Schreiber, B. Loeffler, L. Polerecky, M.M. Kuypers, D. de Beer, Mechanisms of transient nitric oxide and nitrous oxide production in a complex biofilm, ISME J. 3 (2009) 1301-1313. doi:10.1038/ismej.2009.55.

[63] Q. Wang, B.-J. Ni, R. Lemaire, X. Hao, Z. Yuan, Modeling of Nitrous Oxide Production from Nitritation Reactors Treating Real Anaerobic Digestion Liquor, Sci. Rep. 6 (2016) 25336. doi:10.1038/srep25336. 
[64] K.E. Mampaey, B. Beuckels, M.J. Kampschreur, R. Kleerebezem, M.C.M. van Loosdrecht, E.I.P. Volcke, Modelling nitrous and nitric oxide emissions by autotrophic ammonia-oxidizing bacteria, Environ. Technol. 34 (2013) 1555-1566. doi:10.1080/09593330.2012.758666.

[65] R. Yu, K. Chandran, Strategies of Nitrosomonas europaea 19718 to counter low dissolved oxygen and high nitrite concentrations., BMC Microbiol. 10 (2010) 70. doi:10.1186/1471-2180-10-70.

[66] B. Hu, J. Ye, J. Zhao, X. Ding, L. Yang, X. Tian, Characteristics of N 2 O production and hydroxylamine variation in short-cut nitrification SBR process, Water Sci. Technol. 77 (2018) $187-$ 195. doi:10.2166/wst.2017.496.

[67] S.-W. Kim, M. Miyahara, S. Fushinobu, T. Wakagi, H. Shoun, Nitrous oxide emission from nitrifying activated sludge dependent on denitrification by ammonia-oxidizing bacteria., Bioresour. Technol. 101 (2010) 3958-63. doi:10.1016/j.biortech.2010.01.030. 
Mixed Liquor WWTP $\rightarrow$ Lab-scale Respirometry $\rightarrow$ Model Calibration / Validation $\rightarrow \mathrm{N}_{2} \mathrm{O}$ Pathway contribution?
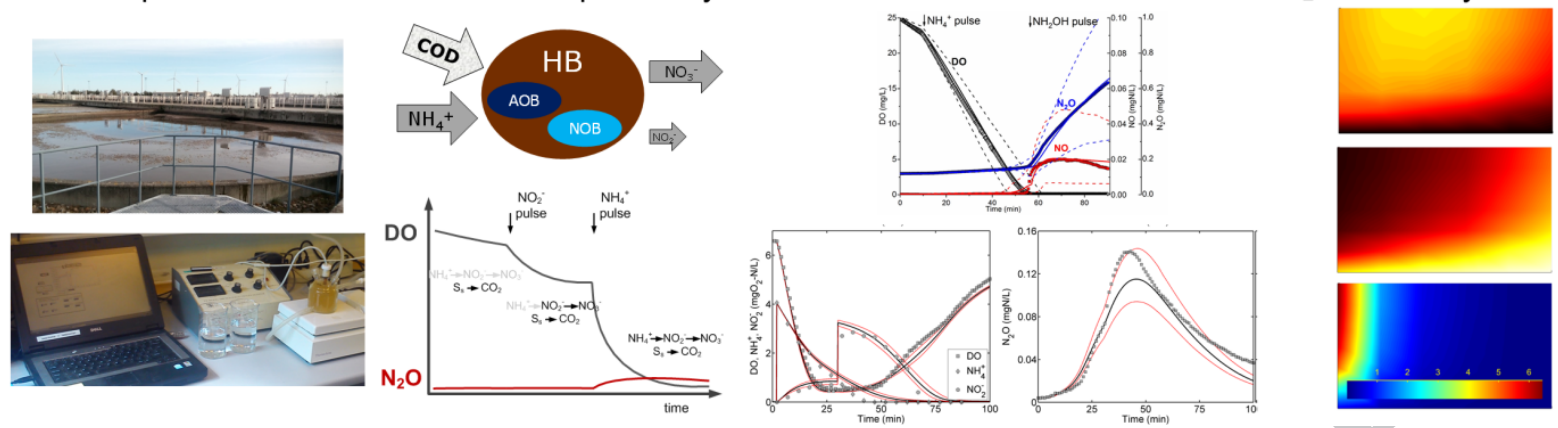